Review

\title{
Current Progress and Future Prospects of Agriculture Technology: Gateway to Sustainable Agriculture
}

\author{
Nawab Khan ${ }^{1}$, Ram L. Ray ${ }^{2, *(D)}$, Ghulam Raza Sargani ${ }^{3, *}$, Muhammad Ihtisham ${ }^{4,5, *}$, Muhammad Khayyam ${ }^{6}$ \\ and Sohaib Ismail ${ }^{7}$
}

Citation: Khan, N.; Ray, R.L.; Sargani, G.R.; Ihtisham, M.; Khayyam, M.; Ismail, S. Current Progress and Future Prospects of Agriculture Technology: Gateway to Sustainable Agriculture. Sustainability 2021, 13, 4883. https://doi.org/10.3390/ su13094883

Academic Editor: Claus G. Sørensen

Received: 3 March 2021

Accepted: 12 April 2021

Published: 27 April 2021

Publisher's Note: MDPI stays neutral with regard to jurisdictional claims in published maps and institutional affiliations.

Copyright: (c) 2021 by the authors. Licensee MDPI, Basel, Switzerland. This article is an open access article distributed under the terms and conditions of the Creative Commons Attribution (CC BY) license (https:// creativecommons.org/licenses/by/ $4.0 /)$.
1 College of Management, Sichuan Agricultural University, Chengdu 611100, China; nawabkhan@stu.sicau.edu.cn

2 College of Agriculture and Human Sciences, Prairie View A\&M University, Prairie View, TX 77446, USA

3 College of Economics, Sichuan Agricultural University, Chengdu 611100, China

4 College of Landscape Architecture, Sichuan Agricultural University, Chengdu 611130, China

5 College of Horticulture and Forestry, Huazhong Agricultural University, Wuhan 430070, China

6 School of Economics and Management, China University of Geosciences, Wuhan 430074, China; khyousafzai@cug.edu.cn

7 Department of Plant Pathology, Sichuan Agricultural University, Chengdu 611130, China; sohaibismail@stu.sicau.edu.cn

* Correspondence: raray@pvamu.edu (R.L.R.); razasargani@sicau.edu.cn (G.R.S.); ihtisham@webmail.hzau.edu.cn (M.I.)

\begin{abstract}
The agricultural industry is getting more data-centric and requires precise, more advanced data and technologies than before, despite being familiar with agricultural processes. The agriculture industry is being advanced by various information and advanced communication technologies, such as the Internet of Things (IoT). The rapid emergence of these advanced technologies has restructured almost all other industries, as well as advanced agriculture, which has shifted the industry from a statistical approach to a quantitative one. This radical change has shaken existing farming techniques and produced the latest prospects in a series of challenges. This comprehensive review article enlightens the potential of the IoT in the advancement of agriculture and the challenges faced when combining these advanced technologies with conventional agricultural systems. A brief analysis of these advanced technologies with sensors is presented in advanced agricultural applications. Numerous sensors that can be implemented for specific agricultural practices require best management practices (e.g., land preparation, irrigation systems, insect, and disease management). This review includes the integration of all suitable techniques, from sowing to harvesting, packaging, transportation, and advanced technologies available for farmers throughout the cropping system. Besides, this review article highlights the utilization of other tools such as unmanned aerial vehicles (UAVs) for crop monitoring and other beneficiary measures, such as optimizing crop yields. In addition, advanced programs based on the IoT are also discussed. Finally, based on our comprehensive review, we identified advanced prospects regarding the IoT, which are essential tools for sustainable agriculture.
\end{abstract}

Keywords: IoT; agriculture advancement; UAVs; sustainable agriculture

\section{Introduction}

In order to increase agricultural production with limited resources, major technological advancements have been implemented throughout much of human history. However, a growing population along with climate change always poses a threat between food supply and demand. The world's population is estimated to reach 9 billion by 2050, which is about a twenty-five percent increase over the current population [1]. However, population growth will be larger, mostly in emerging countries such as Mexico, India, China, and others [2]. Additionally, the urbanization trend is expected to accelerate in developing countries by 2050 . Currently, $49 \%$ of the world's population lives in urban areas, which 
is expected to increase to $70 \%$ by 2050 [3]. Besides, since the living standard is expected to increase in the future, it will further increase food demand, particularly in emerging nations. Due to the continuous increase in the global population, we should be more cautious regarding nutritional values and food quality. To meet future food demands, food production should be doubled by 2050 [4,5]. In particular, grain crops and meat production should be increased from 2.1 billion tons to 3 billion tons, and 200 million tons to 470 million tons, respectively, to meet the world food demand by 2050 [6,7].

Indeed, crops such as rubber, cotton, and chewing gum play a crucial role in various countries' economies. In addition, crop-based bioenergy markets have recently begun to grow. Even ten years ago, 110 million tons of coarse grains (about $10 \%$ of world production) were used for ethanol production alone $[7,8]$. Food security is also threatened by the increased use of food crops for biofuel production, bioenergy, and other industrial uses. These biofuel/bioenergy demands have put further pressure on already scarce agricultural resources. Unfortunately, due to different constraints (e.g., temperature, terrain, and soil and water qualities), only a limited part of the Earth's surface is appropriate for agricultural use. Moreover, the existing farming land is further narrowed because of economic and political factors, including population growth, climate, and land-use patterns, while the rapid urbanization process is continuously putting pressure on the availability of arable land. Thus, since arable land is decreasing, these factors would be major threats to crop production. Additionally, crop production is already reduced due to a lack of arable land over the last few decades [8]. For example, in 1991, arable land for the crop production was 19.5 million square miles, which was $39.47 \%$ of the total agricultural land area, but that area was decreased to 18.6 million square miles in 2013 , which is about $37.73 \%$ of the total agricultural land area of the world and is expected to decrease in the future [9]. Consequently, a larger gap between the demand and supply of food is observed, which becomes apparent and shocking over time.

Further, the quality and quantity of crops rely on climate, topography, and soil characteristics. Major features such as available nutrients, soil types, soil health, insect resistance, and quality and quantity of irrigation determine its adaptability and the quality of certain crops. In most cases, crop characteristics and yields may vary within the same farm plot. Therefore, site-specific analysis or the precision farming technique is required to obtain optimal yields. Besides increasing crop production, growers and farmers need to practice multiple cropping, mixed cropping, year-round cropping, or intensive cropping. To meet these needs, growers and farmers require the latest/advanced technologies and servicesbased techniques to produce more foods with limited land and resources. Farmers/growers must monitor their croplands at a near to real-time scale to apply necessary measures to enhance crop production. For this reason, there is a need for smart agriculture.

Currently, farmers and growers have to spend $70 \%$ of their time monitoring and understanding the status of the crops rather than performing actual farm work [10]. Hence, precise and advanced technologies are required to advance the agricultural sector. Additionally, for sustainable agriculture, the effects of climatic and environmental conditions should be minimal. The Internet of Things (IoT) gives producers better results because of "on-site monitoring" capabilities, allowing them to monitor farms remotely. Wireless sensors help to continuously monitor crops with greater accuracy, and most importantly, they can identify issues at the early growth stages of crops/plants. The latest technologies and tools enhance agricultural operations during the crop growth stages, such as crop harvesting, the transportation of cropping materials, and storage conditions [10]. During these developmental stages of crops, advanced technology, such as the IoT, plays a significant role, making the process efficient for the growers. Currently, several tools, including harvesters, robot weeders, unmanned aerial vehicles (UAVs), and other automatic machines, are beneficial to the growers for crop monitoring. For this purpose, several sensors are installed in the field. These sensors rapidly provide information regarding soil health and crop health, and associated factors. The IoT is a part of the latest agricultural technology, which helps collect data from the field. 
Many institutions and industries are now developing new technologies, such as the IoT, for effective farm management. These technologies help obtain the best results and improvements in their fields and minimize associated inefficiencies [5,11-14]. The latest technology is very affordable to the farmers, although little information related to the IoT is available for them. Despite this, for sustainable agriculture, the IoT is considered an emerging technology and better adaptable by farmers to obtain better crop productions. These new technologies, such as the IoT, provide many improvements in necessary infrastructures, such as the use of cellular devices by internet technology and the scope of various services, including information related to the cloud-based sensors, automation of different farming operations, and making effective decisions. The agriculture sector, which is the leading economic industry, and the backbone of the country, will be revolutionized by the IoT $[5,15]$. Figure 1 presents information related to the primary drivers, which require this advanced technology. Moreover, it demonstrates the significant challenges associated with this technology and its implementation in advanced agriculture, such as a fragmented market, poor connectivity and coverage, investment, lack of new appropriate technology, lack of skilled manpower, and others.

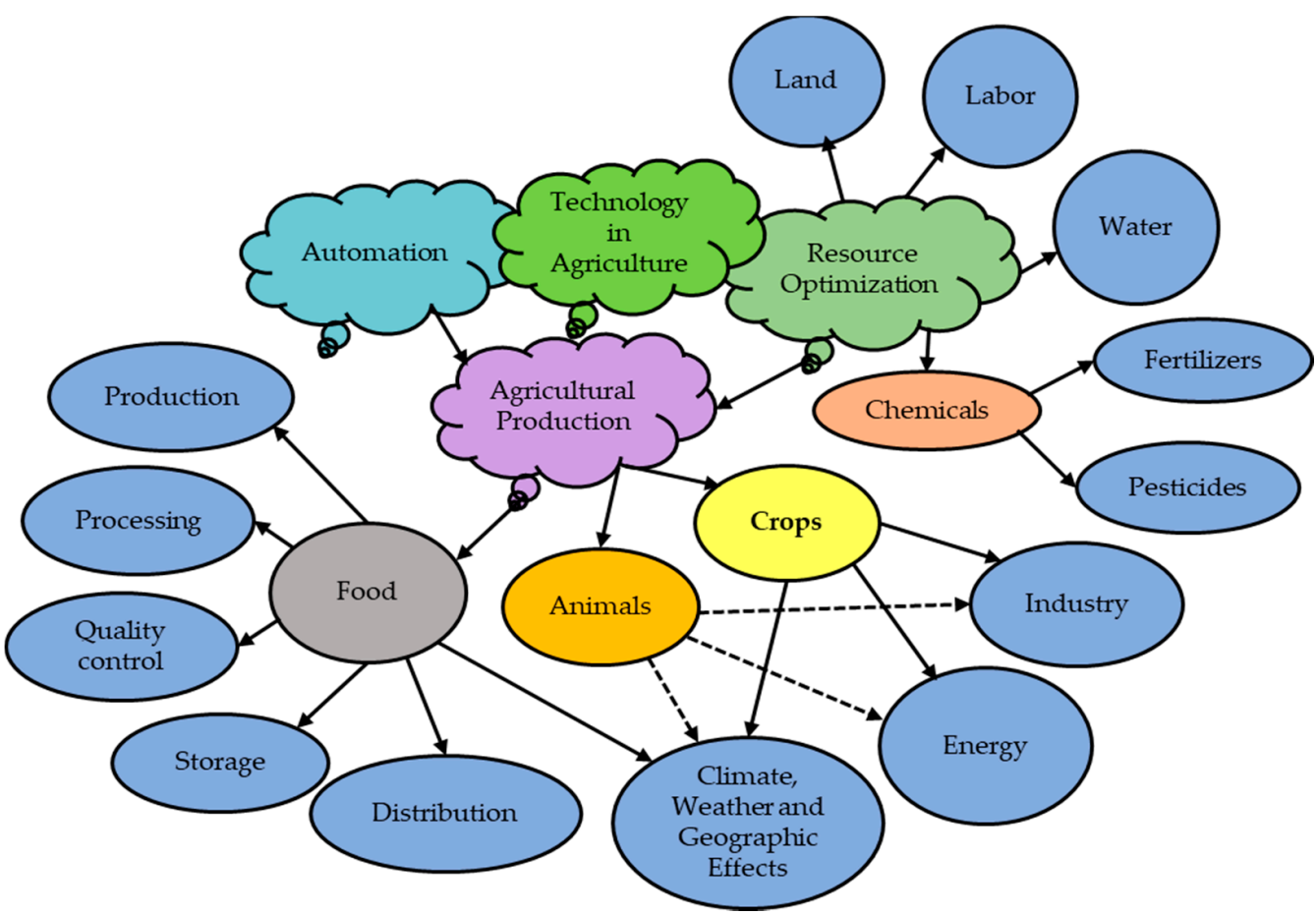

Figure 1. Key driving factors associated with the technology in advanced agriculture. This list is an effort to compile most of the activities/factors associated with agriculture, which require advanced technology. It is not meant to be a comprehensive list as many more driving factors/activities need advanced technology.

For the improvement of the agriculture sector, scientists, researchers, and engineers are developing many new technologies and methods to monitor crops and related field data. Several manufacturing agencies are approaching to provide various devices/tools such as robots, IoT sensors, and UAVs to collect real-time data at much higher resolutions. For this purpose, federal and non-federal agencies are working together to enhance the IoT applications to sustain food safety and security [16-19].

There are ample efforts to emphasize the IoT's role in the farming sector $[20,21]$. Most of the previously published data either did not deliver enough insights or only focused on various IoT-based architectures, prototypes, improved techniques, and how to use the IoT for monitoring applications and associated environment and crop data management [20,22,23]. For example, Villa-Henriksen et al. [24] reviewed past studies for 
IoT applications in arable farming. They focused on IoT architecture represented by device, network, and application layer. Similarly, Navarro et al. [25] conducted a systematic review of IoT solutions for smart farming and focused on the concept, number of publications, and IoT applications in agriculture. Talavera et al. [26] focused on distributions of IoTrelated research work globally, as well as applications of the IoT in communications, energy management, monitoring, and logistics.

This review article analyzed the trends in advanced technology-based agricultural studies, focusing on IoT and UAV applications. Further, it explored many essential issues that should be harnessed to take advantage of the IoT and other latest technologies to transform them into the agricultural industry. The most important contribution of this review is to provide accurate insights into:

- World prospects for agriculture advancement;

- Technology-based limitations faced by the agricultural industry, and the role of major equipment and technologies, such as the IoT, and UAVs, to address these limitations and other issues, such as resource shortages and their precise uses, food quality, environmental pollutions, climate change, and urbanization;

- Highlighting the latest developments in the IoT and other technologies that support advanced agriculture;

- Strategies and policies to consider when implementing the IoT and other technologies in advanced agriculture;

- Key issues in food safety with recommendations to address those issues;

- Future prospects and recommendations of these advanced technologies.

This review article outlines vital information that can support agricultural engineers and researchers, to implement advanced technologies, such as the IoT, UAVs, and others to attain advanced agricultural needs. The remainder part of this review article is organized as follows. The second section discusses methods used in this study. The third section gives an in-depth summary of key applications used in advancing agriculture, such as monitoring soil, irrigation, crop disease, fertilizer application, crop harvesting, and its management. The fourth section provides insights into the role of the IoT in advanced agricultural practices such as greenhouse agriculture, hydroponics, vertical farming, phenotyping. The fifth section highlights the various technologies and equipment used in the agricultural industries to implement the IoT, such as smartphones, wireless sensors, advanced machines, cloud computing. The sixth section embraces the uses of UAVs in advanced agriculture that cannot be achieved even with other latest technologies, which includes soil, water, and vegetation analysis (e.g., planting, irrigation, health assessment of crops, spraying pesticides/herbicides, plant species detection/identification, plant counting and gap detection, crop monitoring). The seventh section discusses food safety and transportation and gives information related to compliance, Laird's Sentrius, Tempreporter, and Critical Control Points Smart Label Radio Configuration Four (CCPSLRC4). This section further explores another critical area where hunger needs to be addressed, and hunger has not received enough attention from researchers. The eighth section identifies current challenges and future prospects in the agricultural industries by highlighting potential research challenges, which includes the IoT, wireless sensors, communications, UAVs and other robots, machine learning and analysis, energy consumption, renewable energy, microgrid and smart grid, hydroponics and vertical farming (VF). Finally, Section 9 concludes this review paper.

\section{Methods}

In the past decades, several studies have been conducted to address critical issues in agriculture to improve agricultural production for food security. With recent advancements in technologies and the potentials to enhance agricultural production using advanced technologies, several researchers put tremendous effort into advancing agriculture. Advanced technologies, such as IoT sensors, wireless sensors, and UAVs, have received exponentially increasing attention from the scientific communities. However, it is always challenging 
for stakeholders and users to select and implement appropriate technology to improve crop production. Recently, a few studies reviewed the IoT-based articles focusing on implementation, application, challenges, potential, and future prospective of the IoT in smart farming and agro-industry [24-26]. However, they mainly focused on IoT-based studies. We reviewed most of the important advanced technology-based studies, which are essential for agriculture advancements either alone or in combinations.

Our strategy was to review advanced technology-based articles. We selected the articles focusing on smart agriculture, precision agriculture, drones/UAVs, wireless communication technologies, the IoT, and smartphone technologies applications in agriculture. We also included articles focusing on monitoring several agricultural components using IoT sensors and wireless devices, such as monitoring soil moisture, vegetation health, plant diseases, crop yield, climatic parameters, and few others. We included most of the technology-based studies conducted in the last two decades that are helpful for agricultural advancements.

\section{Major Agriculture Applications and Services}

All the traditional approaches have been changed and overlapped by advanced technologies, such as the IoT and UAVs. Currently, the implementation of various wireless sensors and IoT sensors leads to the gateway of many innovations for crop improvement. Several traditional crop issues, including disease management, effective irrigation, cultural practices, and drought responses, are currently addressed by these new emerging technologies. Figure 2 depicts the primary applications, wireless sensors, and services hierarchy for advanced agricultural applications. The advanced technologies used to monitor major applications to improve crop productions are discussed below.

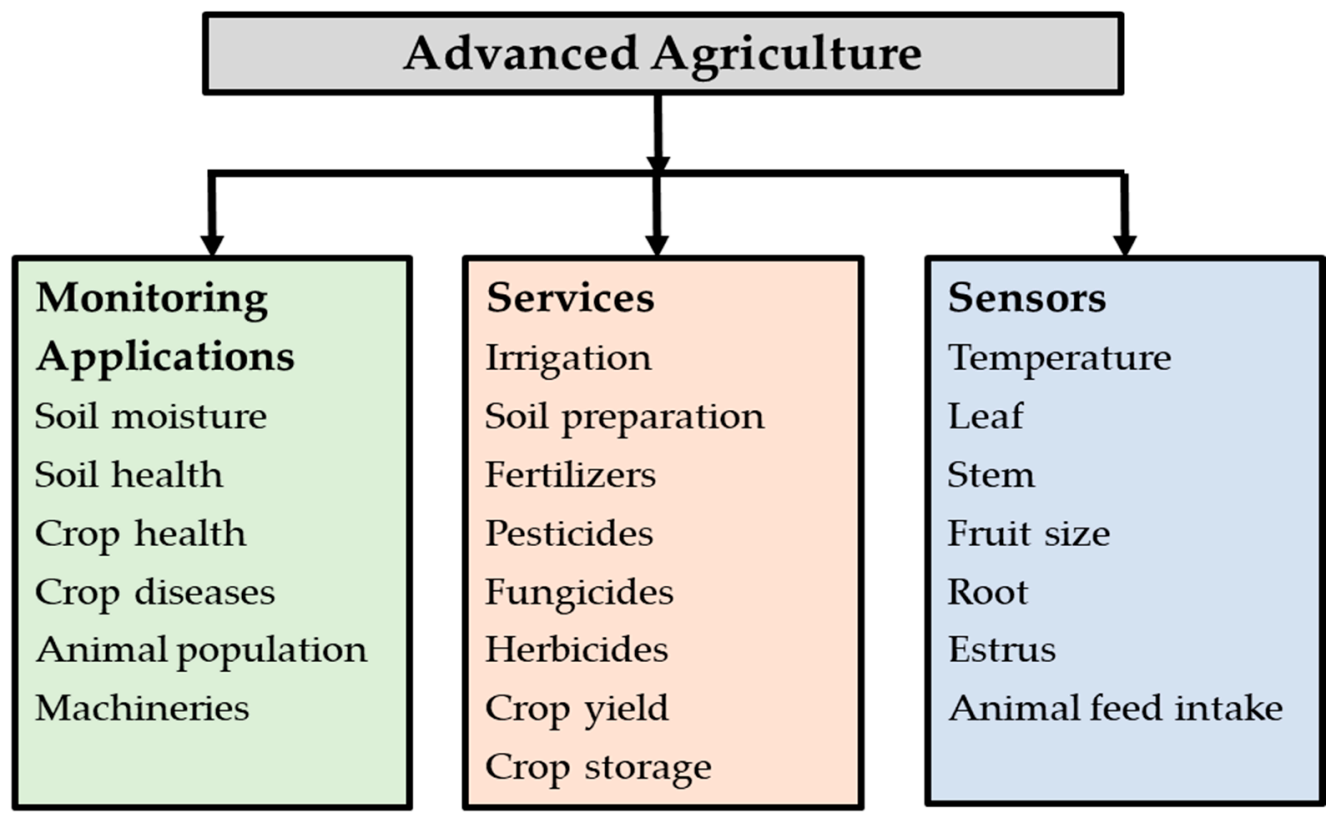

Figure 2. Major applications, services, and sensors for advanced agriculture, modified from Talavera et al. [26].

\subsection{Soil Monitoring}

Soil plays a critical role in plant growth. It is necessary to monitor the soil at the field scale. By obtaining the soil's health information, a grower can make fruitful decisions at different plant developmental stages. The main objective of soil analysis is to measure the content of nutrients present in the soil, which ultimately leads to many treatments to fulfill the level of nutrients. Remarkably, the soil test is suggested annually in the spring season; however, it can be changed according to the local environmental conditions and 
conducted in the winter or autumn season [27]. Several soil factors, such as soil types and soil moisture, are recommended to analyze and quantify fertilizers and irrigation requirements. These primary factors also help provide information regarding the other vital factors, including physical, chemical, biological ones. The soil map helps to identify areas with good soil health and texture for the suitability of seeds, sowing time, and even sowing depth because some plants have deep roots and others have shallow root depths.

Many researchers have recently developed tools, technologies, and devices to monitor soil health. These new tools are the major resources for farmers and growers, which can be used to monitor soil features such as water holding capacity, moisture, chemical, and physical properties. These tools also help monitor soil health, such as salinity, $\mathrm{pH}$, soil organic carbon (SOC), electrical conductivity (EC), nitrogen, potassium, and phosphorus, which help estimate required fertilizers. One of the latest tools introduced by Agro Cares is the Scanner and Lab-in-box, which is known as a laboratory, having complete information by services through which it gives soil status information [28]. This is the modified tool used by many farmers without any laboratory for sample analysis. This tool can analyze about 100 soil samples daily.

One of the major issues for estimating crop water requirements is continuously monitoring soil moisture. To monitor soil moisture, in situ soil moisture sensors, remote sensors, and tools can be efficient strategies for many farms to obtain information about the soil's moisture. There are many satellites in operation to measure soil moisture data at a global scale. These remote sensing products are: (i) the Advanced Microwave Scanning Radiometer Earth Observing System (AMSR-E) (2002-September 2011); (ii) the Soil Moisture Ocean Salinity system (SMOS, 2010-present); (iii) AMSR2 (2012-present); and (iv) the Soil Moisture Active Passive system (SMAP, 2015-present) [29]. For example, Soil Moisture and Ocean Salinity (SMOS) was launched in 2009 and started to monitor soil moisture from May 2010 globally. In addition, in situ wireless soil moisture sensors can also monitor soil moisture at the farm scale.

New tools, including the vision-based and wireless sensors, are used to determine crop factors, such as soil depth, for efficient seeding processes. Several robotic tools are developed for smart farming and improve crop production, such as FarmBot and Agribots, just to name a couple. In agriculture practices, such as sowing seeds, weeding, fertilizing, and irrigating, such tools would help improve crop production if it is implemented at a large scale. Agribots is a type of robot; the agriculture field's location is determined by pairing digital computers with the vehicle vision system. This type of robot works on any agricultural land in which the global positioning system (GPS) helps develop location maps. Sensors that are mounted with light-emitting diodes (LEDs) help provide information regarding the flow rate of seed. Many remote sensors are used for this purpose [30]. These LEDs are the source of receiving radiations that have visible and infrared light waves. Seed movement is monitored through many elements, including light band, voltage output, and receiving element. Measurement of the flow rate of seed is conducted through signals correlated by transferring seeds. Overall, advanced technologies and tools help analyze soils, which further help monitor crop growth and production.

\subsection{Irrigation}

On the Earth, oceans hold $97 \%$ of all water, but it is saline. The other three percent of water is fresh, among which $2 \%$ to $3 \%$ of the water is in the form of glaciers [31,32]. Out of three percent, half percent of freshwater is present as surface water, and the remaining freshwater is groundwater. People have to rely on the half percent of freshwater to sustain their lives. This half percent of freshwater includes water storage in lakes, rivers, and other reservoirs. Agriculture uses almost $75 \%$ of freshwater $[33,34]$. In many countries, such as Brazil, the demand for crops has increased to 75\% [35]. Among several constraints, the lack of proper monitoring tools to estimate crop water requirement is the actual cause of the ad hoc application of irrigation water. For example, the US uses about $80 \%$ of freshwater for irrigation purposes [5]. In the United Nations Convention to Combat Desertification 
(UNCCD) held in 2013, it was found that about 168 countries of the world have a shortage of water for irrigation. Research has showed that there would be a huge water shortage for irrigation throughout the world by 2030 [36].

Due to the increase in irrigation water requirements, freshwater will only be available to those countries that have adopted the best water resources management practice. For this purpose, to reduce the water shortage, awareness programs should be promoted to adopt effective irrigation practices. Many new irrigation techniques, including sprinkler and drip irrigation methods, are used to reduce the losses and water shortage. Traditional approaches, including furrow and flood irrigation, cause the waste of water. Moreover, traditional irrigation approaches (e.g., flooding) reduce many soil nutrients through water losses, which impact crop yield. Robust technologies and tools are needed, which include smart irrigation techniques. The smart irrigation techniques help estimate crop water requirements based on soil types, antecedent soil moisture, and climatic conditions. In this situation, many new tools such as the IoT play a significant role in measuring air and soil humidity, which ultimately leads to the improvement of crops.

Crop improvement and its quality can be enhanced by the effective management of soil and water. The use of the IoT, such as for irrigation management based on the crop water stress index (CWSI), is expected to improve crop efficiency significantly [30]. For this reason, the calculation of the CWSI requires one to obtain a crop canopy at different times and temperatures. A CWSI is a wireless sensor-based monitoring system that includes several crop parameter measurement systems that help estimate moisture status, which is used to estimate irrigation water requirements [11].

\subsection{Crop Disease and Its Management}

Famine in Ireland occurred due to Phytophthora infestans, causing the late blight of potato, which caused many crop losses. Due to this famine, about one million people in Ireland died [37]. In the USA, the southern corn leaf blight caused by Cochliobolus heterostrophus brought famine and crop losses of nearly one billion USD. Later, this crop disease was spread to Canada [38]. The Food and Agriculture Organization (FAO) estimated 20\% to $40 \%$ annual crop loss per year due to crop diseases [39]. Several agricultural management strategies were applied to recover these losses, such as the use of pesticides and fungicides. These approaches are practiced in advanced agriculture since the last century. It is estimated that approximately 500,000 tons of pesticides are used each year in the US alone. In contrast, in other countries of the world, about two million tons of pesticides are applied for disease management [40]. Although these pesticides are used for plant disease management to increase crop production, there are many other harmful aspects to animals and humans' health. It also disturbs the world's ecology and eventually causes severe environmental pollution to the entire ecosystem $[5,41]$.

Many of the advanced technologies, such as the IoT, play a significant role in reducing the usage of these chemicals, which are hazardous to human health. Many crop disease monitoring programs such as crop modeling, the prediction of pests, and weather forecasts are monitored by these advanced and emerging technologies in agriculture. These technologies are considered effective approaches for plant/crop disease management [42,43].

Although treatment, perception, and assessment are important in disease forecasting, monitoring, and management, advanced technologies (e.g., the IoT, wireless sensors, and UAVs) are beneficial for disease identification and pest management. For example, remote sensing technology can be used to capture large areas of agricultural cropland economically. The remote sensors can be used to analyze crop processing, including disease and pests, plant health, and the environment $[43,44]$. This remote sensing tool is low cost and has many advantages, such as a low cost for automatic activation and supporting recovery. For example, recently, the yields of many crops have been severely threatened by the poor pollination process [45]. 


\subsection{Fertilizer}

Plant growth, development, and reproduction mainly depend on the necessary nutrients received from fertilizers or organic amendments. For the development of flower, fruit, and root, three significant nutrients are needed: for leaf growth, nitrogen is necessary; for root development, phosphorus and the expansion of stem and water passage in pant potassium is required [36]. Plant health can be affected by the imbalance application of these fertilizers to the plant. On the other hand, the excessive application of these nutrients and fertilizers to the plant not only affects plant health and causes economic losses but also affects the environment, including qualities of soil, water, and air. For example, only half of the total nitrogen is utilized for crop development, and another half of nitrogen is released into the environment. The imbalanced application of undesired nutrients to the crops causes a negative impact on the environment and climate. It also increases the nutrient level in the soil [46]. New technology such as the IoT is beneficial for the exact estimation of the rate of fertilizers in smart agriculture. These approaches also reduce the negative effect on environmental conditions.

New technology is used to estimate the spatial-temporal application of nutrients for the fulfillment of fertilization, which is relatively less laborious and has maximum efficiency [47]. Generally, the normalized vegetation index (NDVI) is used to monitor vegetation health, which ultimately helps to predict the application of nutrients in the soil. The efficacy of nutrient application can be enhanced by such efficient methods, which ultimately reduces the other effect on the environment. Many recent enabling technologies such as geographic information systems (GIS) [48], variable rate technology [49], and global positioning systems (GPS) [50,51] are used to estimate nutrients in the field [52-54]. For the betterment of crops, it was observed that fertilizers are the best source for improving crop productions, and they can be triggered by only the use of new tools and technology known as the IoT [55].

\subsection{Crop Harvesting Monitoring and Forecasting}

Moisture level, the flow of grain mass, crop yield, and quantity or number of grains per crop are monitored and diagnosed by the yield monitoring system. To analyze the crop's overall performance, it is necessary to check the level of the moisture and crop yield. Crop monitoring during the growing period is one of the essential processes. The measurement of crop yield is not only critical at the time of harvest, but it is also important to measure crop yield before the harvesting and during the crop's developmental processes. Various aspects are required for monitoring crop yield, including a high level of pollination, particularly when the environment is changing; there is a need for the prediction of seeds [56-58].

Crop forecasting is a technique that predicts yields before harvest occurs. Such forecasts help farmers make near-term plans and decisions. Moreover, the accurate harvesting time can be estimated by the analysis of crop maturity and its quality. The monitoring process can also judge many of the fruit factors such as fruit color, size, quality, and developmental stages. Crop disease management strategies and other developmental stages such as crop yield and its quality can be enhanced by crop prediction. For this, awareness about the appropriate harvesting schedule is necessary for the betterment of crops. Figure 3 indicates a typical snapshot of the farm area network (FAN), which gives real-time portraits of the whole agricultural field to the farmer.

A new technology, such as a developed yield monitor, can be correlated with any machine which is used for harvesting. The yield monitor tool can also be connected with a smartphone application named FarmRTX, which shows accurate harvesting data. It ultimately processes data to the manufacturer's web-based program [59]. This smartphone application can be used to generate high-defined mapping tools and transfer them with other experts and growers to export to the other farming tools for monitoring crop yield. 


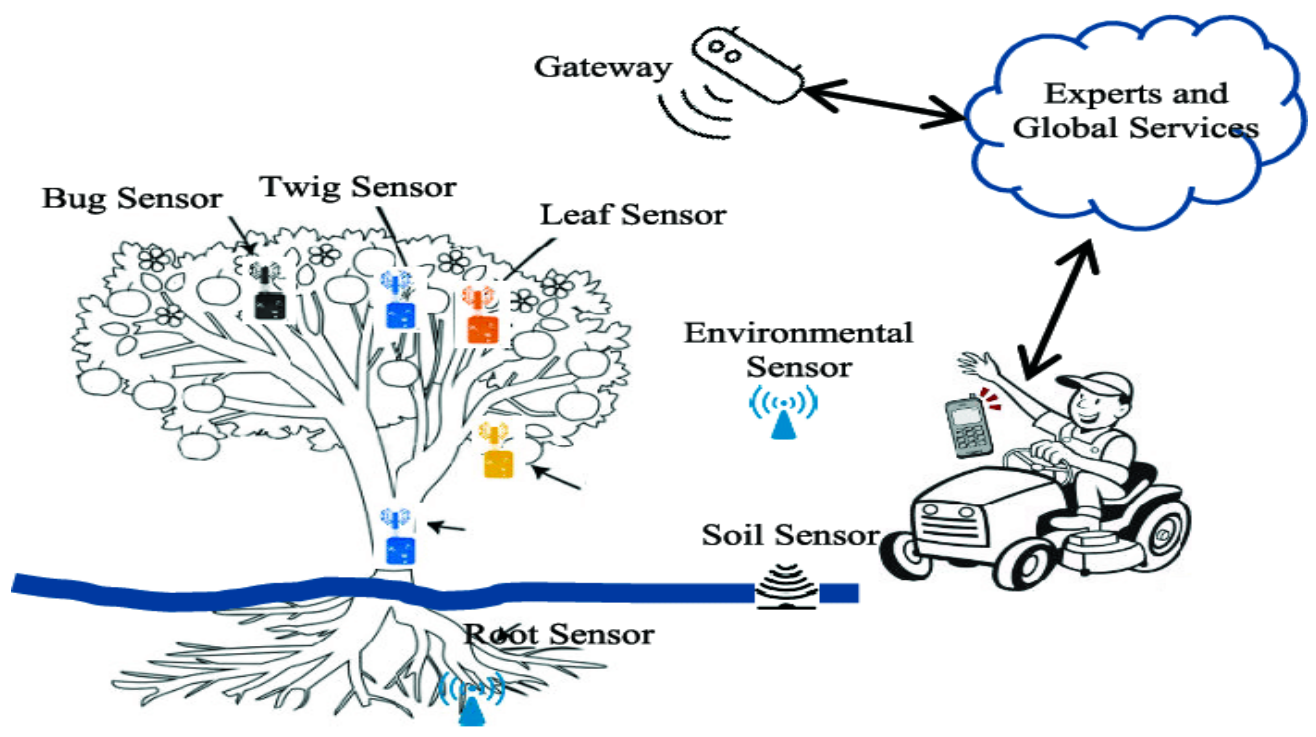

Figure 3. Internet of Things (IoT)-based farm area devices [5,11-14].

\section{Advanced Agricultural Approaches}

Human beings exist for a relatively short time in history, so the adaption of novel techniques of enhancing food quantity and quality is not advanced. For increasing crop development and yield, farmers have applied many measures, such as pesticides and fertilizers. Although there are other management strategies such as greenhouses, hydroponics, vertical farming, etc., for increasing crop production, these measures are not enough to fill this gap. Growers should apply new devices such as the IoT for agriculture advancement.

\subsection{Greenhouse Agriculture}

Growing plants in controlled conditions is a relatively new technology and a type of advanced agriculture. This technique became popular in the 19th century when a number of greenhouses were built in Italy, the Netherlands, and France for growing plants, unseasonal vegetables, and fruits. This type of new agriculture technology was enhanced in the 20th century, and countries with climate/weather issues started to apply this technology rapidly [60]. Crops that are grown in a controlled environment require minimum inputs because crops grow under controlled conditions. This controlled environment is developed in the greenhouse. Due to this controlled environment, seasonal and unseasonal crops are grown anywhere and at any time in the world. Several new toolkits such as wireless communication, mobile devices, and other internet devices are used to adopt this technology. Benke and Tomkins [61], who conducted a comprehensive analysis, reported that advanced toolkits could help to adopt greenhouse technology. Various other toolkits, including prototype-based internet, are used to monitor weather parameters, such as temperature, pressure, and humidity.

\subsection{Hydroponics}

The most advanced method for seasonal and unseasonal crops is to grow in water under controlled conditions without a soil medium. In this approach, nutrients and fertilizers are applied through the irrigation system. When VF and hydroponics are used in combination, every square meter farm can use almost $95 \%$ less water and nutrients without using any chemicals [62]. In a hydroponics system, the accuracy of nutrient measurement is critical. Therefore, a highly reliable wireless control system for tomato hydroponics was proposed $[63,64]$. In this method, monitoring the water content and its accuracy is essential. In a prototype based on wireless sensors, it was proposed to provide the cultivation of crops in hydroponics by the turnkey solution, which gives the measurements and estimations regarding the plant growth in the absence of soil media. Furthermore, there was a new tool, 
a compact sensor that uses the oscillator circuit. The primary purpose of this device is to monitor the occurrence and concentration of different fertilizers and irrigation levels [65].

\subsection{Vertical Farming (VF)}

Arable land is decreasing with the increase in the human population, urbanization, pollution, and soil erosion. The VF is the progressive technique of advanced agriculture, which allows one to grow the crops and plants in controlled conditions, and significantly, this efficiently decreases the consumption of many resources. VF is the most suitable agricultural approach in which a small patch of land is required to cultivate crops compared to traditional farming. This conventional farming technique needs several resources, not only for crops $[65,66]$. Unfortunately, current farming practices, based on industrialized agriculture, are destroying soil health much more than natural reconstruction. Overall, it has been reported that the soil erosion rate is higher (10 to 40 times) than the formation rate of the soil. Recent measures used for farming cause a loss of healthy soil from the agricultural land, which is a major hazard to food production in the upcoming days. Besides, as we assume, about $70 \%$ of the freshwater is only utilized for the farming system, which will enhance the pressure on the existing water reservoirs or storage. VF is the solution for many limitations and challenges for land management and a shortage of freshwater.

For this purpose, according to Mirai, a Japanese-based indoor farming tool provides data of about 25,000 square meters of Japanese agricultural farms. Notably, it utilizes the minimum level of irrigation water compared to the production of crops in outdoor conditions and $40 \%$ of the energy [67]. The aviation farm is the leader of VF, where the yield of agricultural products in New York increased by 390 times, while water consumption was reduced by $95 \%$ [68]. Carbon dioxide is one of the crucial factors in farming as compared to other aspects of agriculture. For the estimation of carbon dioxide, a new toolkit, which is a non-dispersive infrared (NDIR) carbon dioxide wireless sensor that participates in the complete control of VF $[69,70]$ connected to mobile devices and wireless communication technologies. These devices can automatically check the crops at each development phase.

\subsection{Phenotyping}

The smart methods discussed earlier seem more promising for advancing agriculture, as they have been utilized to grow various crops in a conducive environment. Besides, some advanced technologies are evaluated to control their limitations through advanced sensing and communication technologies, thereby further enhancing crop capabilities. The most efficient method is the phenotyping approach, the advanced genetic engineering technique, and biotechnology, which correlates the genetic sequences of crops for agronomical and physiological aspects, as described in Figure 4. In the last few decades, several modifications have been made in the field of genetic engineering and biotechnology. However, many factors such as grain weight and disease resistance have not been dealt with yet due to a lack of efficient techniques.

Recent advancements have described that phenotypes play an efficient role in determining many quantitative factors such as plant growth, disease resistance, crop yield, and crop quality in advanced genetic engineering and biotechnology [71]. One of these tools is image-based phenotypes and sensors, which monitor how these resolutions cannot accommodate numerous screen stimulants and help them understand the mode of action, thereby participating in their success [72]. Moreover, other tools such as the IoT and CropQuant-based phenotypes techniques are used to analyze many crop-related factors such as crop traits by genetic engineering and biotechnology for advanced agriculture [73]. Moreover, an automated production site-controlled program was established to continue the generation of data by this program. Machine learning modeling and feature analysis algorithms are given to exploit the association among phenotypes, growth environments, and genotypes. 


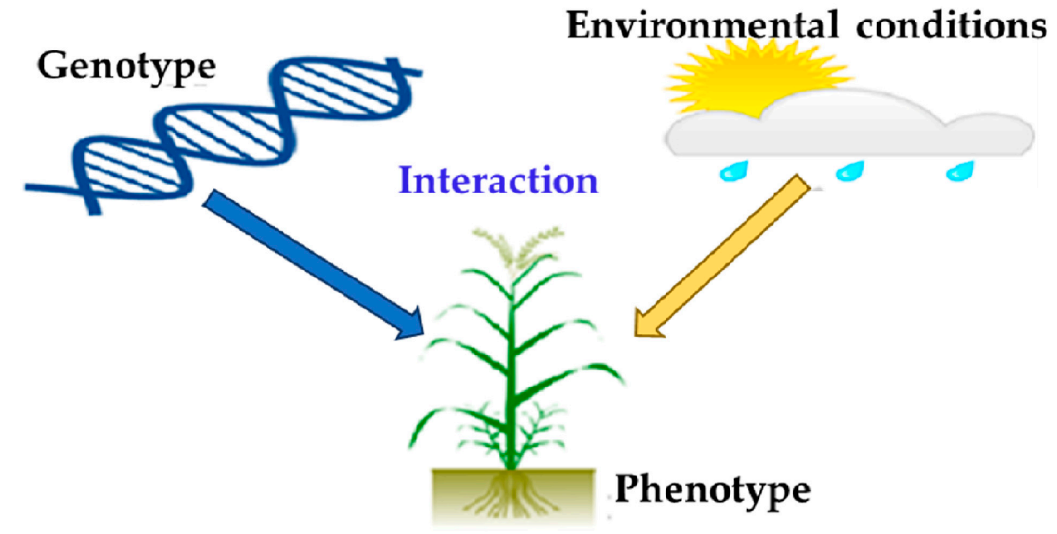

Figure 4. The process of phenotyping.

\section{Major Equipment and Technologies}

In traditional agriculture, most farming measures are applied by heavy machinery, including harvesters, massive robots, and tractors. Several communications and remote sensing techniques are used to operate these machines. In advanced farming, for many crop-related practices such as irrigation, sowing, fertilizer application, and harvesting of crops, these machines and equipment are supported by GIS and GPS technologies, which are very accurate, efficient, and precise. Moreover, other agricultural measures (the site-specific management of crops) cannot replace these advanced techniques. The development of contemporary agriculture needs the efficiency of gathered information and generally has two parts [9]. First, remote sensing programs with multifunctional devices, including UAVs, aircraft, and satellites, are needed. Second, many other devices, such as ground and remote sensors, are required for particular functions at different locations. A GPS device can be used to identify the data collection spot's location, which can be used for location-specific processing.

Over the past few decades, agriculture has shifted from small and medium-sized agriculture to highly industrialized and commercial agriculture. This shift plays an important role in advancing the agricultural industry like other developed industries because, in agriculture, data, control, and measurement are significant factors in accomplishing equality among production and cost to enhance outputs. For this purpose, the IoT is a fundamental approach for advancement and benefits in agriculture, which are well planned, managed, and automated. According to this information, between 2017 and 2022, the world's advanced agricultural industry is expected to grow by $19.3 \%$ in one year and reach USD 23.14 billion in 2022 [33].

\subsection{Smartphone}

Although strong cellular communications coverage is lacking, cellular communications are the main communication methods in remote regions. Whenever a contractor is needed to update most agricultural communities, smartphones are a powerful communication technology and the primary method of communication. Recent advances in the smartphone industry have led to a sharp drop in prices, which has made the sector more attractive, especially for small farmers in rural regions. According to the global system assessment for mobile communications, this proportion is almost eight percent [74]. Moreover, features and flexibility, including GPS, microphone cameras, accelerometers, proximity, and gyroscopes, have attracted IT technicians who are creating more attractive smartphone functions to satisfy many demands of farmers [75-78].

Due to advancements in the research, experts have developed various new tools and approaches strategically to implement smartphone technology in agriculture. Several developing countries, such as Ghana, Kenya, Nigeria, Uganda, Mali, and Zimbabwe, are adopting advanced tools and techniques in agriculture [79-82]. Moreover, smartphone technology is used in many countries, such as China, Turkey, India, and several African 
countries, which are listed above. These countries are implementing this advanced technology to increase agriculture production and boost their economies [83-86]. The use of smartphones in the agricultural sector significantly depends upon numerous aspects. For this purpose, studies were conducted to determine smartphones' usage for several agriculture measures [87].

Table 1 presents the classification of smartphone-related sensors that have attracted experts to use them for different agricultural purposes. Table 2 includes some significant smartphone applications generated for numerous agricultural approaches, as well as their functions and applications.

Table 1. Uses of smartphone sensors in advanced agriculture. GPS: global positioning system.

\begin{tabular}{|c|c|c|c|}
\hline Smartphone Sensors & Purpose & Common Agriculture Usages & References \\
\hline Image sensor (Camera) & Take images of any object & $\begin{array}{l}\text { Leaf area index (LAI), fruit ripeness, harvest } \\
\text { readiness, soil erosion, disease detection. }\end{array}$ & [87] \\
\hline Accelerometer & $\begin{array}{l}\text { Measures acceleration that used to } \\
\text { observe the tilting motion and } \\
\text { orientation of the object }\end{array}$ & $\begin{array}{l}\text { Rotation of camera during use, machine } \\
\text { activities, or detecting workers. }\end{array}$ & [88] \\
\hline GPS & $\begin{array}{l}\text { Provides location, measuring the } \\
\text { latitude and longitude of devices }\end{array}$ & $\begin{array}{l}\text { Used for location information, land } \\
\text { measurement, and crop mapping }\end{array}$ & [89] \\
\hline Microphone & $\begin{array}{l}\text { Detects usual or unusual sound and } \\
\text { transform into electrical waves }\end{array}$ & $\begin{array}{l}\text { Maintenance of machine, detection of bugs, } \\
\text { and making audio queries. }\end{array}$ & [90] \\
\hline Gyroscope & $\begin{array}{l}\text { Senses the angular velocity to track the } \\
\text { target rotation/turn }\end{array}$ & $\begin{array}{l}\text { Canopy structure measurement and } \\
\text { equipment movement. }\end{array}$ & [89] \\
\hline Inertial Sensor & $\begin{array}{l}\text { Utilizes accelerometer and gyro to } \\
\text { determine the object altitude in relation } \\
\text { to the inertial system }\end{array}$ & $\begin{array}{l}\text { The precise distance of the plant, leaves, } \\
\text { and/or any other object is measured from } \\
\text { the camera. }\end{array}$ & [91] \\
\hline Barometer & Measure air pressure & Measure air pressure & [92] \\
\hline
\end{tabular}

Table 2. Essential applications of smartphones for various agriculture functions.

\begin{tabular}{|c|c|c|c|}
\hline Mobile Apps & Application & Feature/Achievement & References \\
\hline PETAFA & GIS & $\begin{array}{l}\text { It provides information on the normalized difference vegetation index } \\
\text { (NDVI) for different crops at various life cycles. However, it distributes } \\
\text { geo-referenced soil analysis through packages. }\end{array}$ & [5] \\
\hline LandPKS & Soil Assessment & $\begin{array}{l}\text { Land management has long-term potential, depending on weather, } \\
\text { topography, and relatively static soil properties (such as depth, soil texture, } \\
\text { and mineralogy). The app aims to increase growers' understanding of the } \\
\text { land potential and climate change adaptation and mitigation activities. }\end{array}$ & [93] \\
\hline PocketLAI & Irrigation & $\begin{array}{l}\text { The app estimates the leaf area index (LAI), which is the main factor } \\
\text { determining plant water requirements. It uses a moving camera and } \\
\text { accelerometer sensor to acquire images at } 57.5^{\circ} \text { under the hood while the } \\
\text { user keeps rotating the device along its central axis. }\end{array}$ & [94] \\
\hline AMACA & $\begin{array}{l}\text { Machinery or } \\
\text { Devices }\end{array}$ & $\begin{array}{l}\text { Equipment costs are a significant part of crop expenditure. The application } \\
\text { helps estimate the mechanical and implantation costs in different field } \\
\text { operations. Follow the cutter-driven quality function deployment (QFD) } \\
\text { approach to meet your expectations with user expectations for application } \\
\text { design features. }\end{array}$ & [95] \\
\hline eFarm & GIS & $\begin{array}{l}\text { eFarm is crowdsourcing and human perception tool that collects } \\
\text { geo-tagged agricultural land information at the parcel level. Ideal for } \\
\text { mapping, sensing, and modeling of agricultural land systems research. }\end{array}$ & [84] \\
\hline Ecofert & $\begin{array}{l}\text { Management of } \\
\text { Fertilizers }\end{array}$ & $\begin{array}{l}\text { Ecofert helps manage the best use of fertilizer files. It calculates the best } \\
\text { fertilizer combination based on the required nutritional solution and } \\
\text { considers the needs of different crops. In addition, it considers fertilizer } \\
\text { costs based on current market prices. }\end{array}$ & [96] \\
\hline AgriMaps & Land Management & $\begin{array}{l}\text { The application follows an evidence-based, site-specific approach to make } \\
\text { recommendations for cropland management. Compared to other related } \\
\text { applications, it provides a platform for spatial data visualization with a } \\
\text { wider range of geospatial information. }\end{array}$ & [97] \\
\hline
\end{tabular}


Table 2. Cont.

\begin{tabular}{|c|c|c|c|}
\hline Mobile Apps & Application & Feature/Achievement & References \\
\hline SWApp & Irrigation & $\begin{array}{l}\text { The developers of this app specifically targeted arid regions, as irrigation } \\
\text { problems are more common in these regions. The application provides a } \\
\text { reliable and economical solution for monitoring soil moisture and even } \\
\text { considers weather history. }\end{array}$ & [98] \\
\hline SnapCard & $\begin{array}{l}\text { Sparing } \\
\text { applications }\end{array}$ & $\begin{array}{l}\text { The SnapCard application was developed for the field analysis of spray } \\
\text { collectors based on imaging analysis. It uses different cell phone sensors } \\
\text { and follows five imaging methods to quantify droplet deposition and size. }\end{array}$ & [99] \\
\hline Weedsmart & Weed Management & $\begin{array}{l}\text { This app can increase weed management in the pasture. Based on the } \\
\text { answers given to nine questions about pasture farming systems, this } \\
\text { application assesses herbicide resistance and the risk of weed seed banks. }\end{array}$ & [100] \\
\hline Village Tree & Pest Management & $\begin{array}{l}\text { Village Tree provides smart pest management solutions by collecting plant } \\
\text { pest and disease reporters. It uses a crowdsourcing method and sends } \\
\text { images along with location knowledge to warn other growers that may be } \\
\text { affected. }\end{array}$ & [101] \\
\hline cFertigULF & Fertigation & $\begin{array}{l}\text { The tool measures the amount of fertilizer and water required for major } \\
\text { crop types based on different crop growth systems and multiple } \\
\text { fertilization techniques. Farmers can achieve the precise application of } \\
\text { water and other nutrients in greenhouse farming. }\end{array}$ & [102] \\
\hline
\end{tabular}

\subsection{Agricultural Communication}

The timely communication and reporting of information are considered to be the central part of advanced agriculture. The strong connection and participation of many factors are needed to retrieve efficient and significant purposes. Telecom operators play an essential role in disseminating communication reliability in agriculture development. Moreover, expanding the advancement of the IoT and widespread knowledge to improve the advanced agricultural industry needs a highly efficient management system. Many factors, including coverage, energy consumption, reliability, and cost, are significant and necessary before selecting a communication method.

\subsubsection{Cellular Communication}

Depending on the purpose and bandwidth requirements, a cellular communication mode increase from $2 \mathrm{G}$ to $5 \mathrm{G}$ might be appropriate. Besides, the reliability and even accessibility of cellular networks is a key factor in rural areas. To solve this major problem, information transmission through satellite is another important option. Still, in this case, the price of this communication mode can be very high, which makes it inappropriate for small and medium-sized farms. The choice of communication model also relies on the requirements of the application. For example, some farms require sensors to operate at a low data rate, but they need to work for a long time and require a longer battery life. In this case, the new series of the low-power wide area network (LPWAN) is considered to be an excellent answer for cellular networks. The LPWAN has a longer battery life and has a more massive connection range, and an affordable price (2 to 15 USD) [103]. Currently, crop and pasture management are the two main applications where LPWAN networks are very suitable, and due to their success, they can be used for many other agricultural applications [104]. Generally, wireless sensors used in agricultural applications are divided into three main categories according to the communication information rate and power consumption (Table 3). 
Table 3. Data and power specifications of wireless sensors are often used for modern farming.

\begin{tabular}{llrl}
\hline \multicolumn{1}{c}{ Communication/Data Type } & \multicolumn{1}{c}{ Possible Applications } & Expected Data Size & $\begin{array}{c}\text { Power Consumption } \\
\text { (Active Mode) }\end{array}$ \\
\hline Small-sized data and power consumption & $\begin{array}{l}\text { Air temperature and/or wind } \\
\text { speed, soil, leaf thickness/color } \\
\text { (chlorophyll), fruit size, flower }\end{array}$ & $100 \mathrm{~s}$ of bytes & $\begin{array}{l}\text { Less than an mA } \\
\text { (fraction of mA) }\end{array}$ \\
$\begin{array}{l}\text { Medium-sized data medium power } \\
\begin{array}{l}\text { consumption } \\
\text { Large size data and power consumption }\end{array}\end{array}$ & $\begin{array}{l}\text { Acoustic sensors } \\
\text { Video streaming cameras }\end{array}$ & $10 \mathrm{~s}$ of Mb & $10 \mathrm{~s}$ of mA $\mathrm{sb}$ per minute \\
\hline
\end{tabular}

\subsubsection{Bluetooth}

Bluetooth is an essential wireless communication mode that links small-sized devices over short distances. There are many IoT agriculture devices that are Bluetooth enabled, such as Farm note Air gateway and Color sensor work with Bluetooth-enabled sensors. Bluetooth has an ubiquitous nature, due to which it is studied as suitable equipment for multi-tier farming functions [105].

\subsubsection{Zigbee}

Zigbee is mainly created for a comprehensive range of applications, particularly to replace non-standard equipment. According to application needs, devices based on this etiquette can be one of the three categories: router, coordinator, and end-devices. Besides, Zigbee networks support three different topologies, namely Cluster Tree, Start, and Mesh [106]. Based on these traits and contemplating the needs of agricultural applications, ZigBee can perform a significant role, particularly for the environments of greenhouses that often require short-range transmissions. During different parameter observations, actual-time information from the sensor nodes is transmitted to the terminal server via Zigbee $[107,108]$. For applications such as fertilizers and irrigation, the ZigBee module can be used for transmission, such as in drip irrigation, to check the soil moisture content.

\subsection{Sensor Devices}

Among all the devices used in advanced agriculture today, sensor devices are highly critical and perform a crucial role in collecting crop status and other information. Sensor devices can be utilized separately or in the group as needed. Moreover, sensor devices are used for advanced farming because of their robust technology. Next, the discussion is based on the working process and purpose of the main sensor types and their benefits. The major sensor devices used in advanced agriculture are listed in Table 4.

Table 4. Types of sensor devices.

\begin{tabular}{cl}
\hline Wireless Sensors & \multicolumn{1}{c}{ Employment } \\
\hline & $\begin{array}{l}\text { Telematics sensors are the leading equipment used for communication, an agricultural-based } \\
\text { toolkit, which is the most accurate and precise communication tool. This application is mainly } \\
\text { Telematics Sensors } \\
\text { information of the machine's working status, collect information about areas, locations, and } \\
\text { assist in locating travel routes. These programs help farming managers automatically store } \\
\text { and record information correlated with agriculture. } \\
\text { Remote sensing tools are used to capture and store geographical information and several } \\
\text { environmental and climatic parameters. Moreover, it helps in managing, manipulating, } \\
\text { displaying, and analyzing geographical and spatial information. These sensors help assess } \\
\text { several factors, such as forecasting, monitoring, yield assessment, crop evaluation, land } \\
\text { degradation, and pest management (e.g., using LiDAR, satellite, UAVs). For example, the } \\
\text { Argos sensor can be used for processing, disseminating, and collecting global-based data and } \\
\text { is compatible with smartphone platforms. }\end{array}$ \\
\hline
\end{tabular}


Table 4. Cont.

\begin{tabular}{|c|c|c|}
\hline Wireless Sensors & Employment & References \\
\hline Acoustic Sensor & $\begin{array}{l}\text { Acoustic sensors provide other tools for farm management, such as weeding and fruit } \\
\text { harvesting. The major advantage of this advanced technology is its low price with quick } \\
\text { response capabilities, particularly when considering convenient devices. }\end{array}$ & {$[33,117,118]$} \\
\hline $\begin{array}{l}\text { Light Detection } \\
\text { and Ranging } \\
\text { (LIDAR) }\end{array}$ & $\begin{array}{l}\text { This technology is utilized in different agricultural applications, including segmentation, land } \\
\text { mapping, farm 3D models, determining soil types, yield prediction, soil loss, and monitoring } \\
\text { erosion. Moreover, LiDAR is also utilized to monitor dynamic measurements, such as leaf } \\
\text { area and fruit. }\end{array}$ & [119-124] \\
\hline Optical Sensor & $\begin{array}{l}\text { These sensors use the phenomenon of light reflection to help measure soil organic matter, soil } \\
\text { moisture, and color, the presence of minerals and their composition, clay content, etc. These } \\
\text { sensors can be used to evaluate the soil's ability to reflect light based on different parts of the } \\
\text { selector's magnetic field. }\end{array}$ & {$[125,126]$} \\
\hline $\begin{array}{l}\text { Ultrasonic Ranging } \\
\text { Sensor }\end{array}$ & $\begin{array}{l}\text { This type of sensor can be one of the best choices in various agricultural applications because } \\
\text { of its low price. It is easy to use, and its sampling rate can easily be adjusted/modified. } \\
\text { Frequent uses are tank monitoring, spray distance measurement (for example, boom height } \\
\text { and width control for uniform spray reporting, object detection, and collision avoidance), and } \\
\text { crop canopy monitoring. }\end{array}$ & [127-129] \\
\hline $\begin{array}{l}\text { Optoelectronic } \\
\text { Sensor }\end{array}$ & $\begin{array}{l}\text { Optoelectronic sensors can distinguish plant types; hence, they help to detect weeds, and } \\
\text { other plants, particularly in wide-row crops. Optoelectronic sensors are also capable of } \\
\text { differentiating between vegetation and soil from their reflection spectra. }\end{array}$ & [130] \\
\hline $\begin{array}{l}\text { Electromagnetic } \\
\text { Sensor }\end{array}$ & $\begin{array}{l}\text { Electromagnetic sensors are used to record conductivity and transient electromagnetic } \\
\text { responses, identify electrical responses and adjust variable-rate applications in practical } \\
\text { situations. Sensors based on this technology use electrical circuits to measure the ability of } \\
\text { soil particles to conduct or accumulate charge, which is mainly accomplished by two } \\
\text { methods; contact or non-contact. }\end{array}$ & [131] \\
\hline $\begin{array}{l}\text { Electrochemical } \\
\text { Sensor }\end{array}$ & $\begin{array}{l}\text { This is used to assess soil characteristics to analyze the soil's nutrient level, for example, } \mathrm{pH} \text {. } \\
\text { Standard chemical soil assessment methods are often time-consuming and expensive and can } \\
\text { be simply replaced with these advanced sensors. These sensors are used to measure macro } \\
\text { and micronutrients, salinity, and pH in the soil precisely. }\end{array}$ & {$[132,133]$} \\
\hline $\begin{array}{c}\text { Mechanical } \\
\text { Sensors }\end{array}$ & $\begin{array}{l}\text { Mechanical sensors evaluate the mechanical resistance (compaction) of the soil to indicate } \\
\text { variable compaction. Mechanical sensors enter or pass through the soil and record forces } \\
\text { evaluated by strain gauges or load cells. }\end{array}$ & [134] \\
\hline Airflow Sensor & $\begin{array}{l}\text { These sensors measure the soil's permeability and moisture content and identify the soil } \\
\text { structure to distinguish different soil types. Measurements can be made in a single position or } \\
\text { dynamically during movement, for example, in a fixed position or mobile mode. }\end{array}$ & [135] \\
\hline Mass Flow Sensor & $\begin{array}{l}\text { This sensor is used for yield monitoring because it provides yield information by measuring } \\
\text { the amount of grain flow (for example, when passing through a combine harvesting). }\end{array}$ & {$[136,137]$} \\
\hline $\begin{array}{l}\text { Eddy } \\
\text { Covariance-Based } \\
\text { Sensor }\end{array}$ & $\begin{array}{l}\text { This sensor can be utilized to quantify the exchange of water vapor, carbon dioxide, methane, } \\
\text { and other hydrologic and climatic parameters. This eddy covariance technique provides a } \\
\text { robust technique to quantify the gas fluxes among soil, vegetation, and atmosphere, which } \\
\text { are essential for most agricultural applications in various ecosystems. }\end{array}$ & {$[134,138]$} \\
\hline SWLB Sensor & $\begin{array}{l}\text { Soft water level-based (SWLB) sensors are utilized in advanced agricultural watersheds to } \\
\text { monitor hydrological behavior, including flow and water level, inflexible time-step acquisitions. }\end{array}$ & {$[9,136]$} \\
\hline
\end{tabular}

Note: This list is an effort to compile most of sensors used in the advanced agriculture. It is not meant to be a comprehensive list as many more sensor devices are used in agriculture.

\subsection{Advanced Machines Used to Advance Agriculture}

As technology advances, most manufacturers provide tractors with automatic drives. This equipment is not advanced because self-driving tractors were already on the market even before semi-autonomous vehicles. One of the major benefits of self-driving tractors is the capacity to prevent re-entering in a similar area or a similar row via decreasing overlaps with less than an inch. Moreover, they can create extremely accurate turns without a driver. The device provides higher accuracy and reduces errors, especially when spraying pesticides or target weeds; these are almost impossible when people control the machine.

Although there are no fully automated tractors/machines in the market today, many scientists, researchers, and manufacturers are working to develop the new equipment. Based on the future needs of high-tech new tractors, it is expected that about 700,000 new tractors outfitted with features such as tractor guidance or automatic steering will be sold 
by 2028 [5,139]. Further, it is expected that about 40,000 unmanned driving, completely autonomous cars (level 5), and tractors will be sold by 2038 [109].

However, most farmers cannot afford such advanced farming machines, and most tractor service providers and manufacturers operate far below their potentials. Considering these challenges, for example, Hello Tractor has developed a solution to these problems. The company has developed a low-cost monitoring device that can be installed on any tractor, providing powerful software and analysis tools $[113,140]$. The benefits of this device are twofold: it ensures that most growers can afford the tractor's total cost while monitoring the condition of the tractor and reports if any problems occur. The software connects tractor owners to farmers who need tractor services, just like Uber's tractors. Another major example is Case IH's Magnum series tractors, which use on-board cameras and light detection and ranging (LiDAR) sensors to detect the object that helps avoid collision and control accidents caused by agricultural vehicles [141].

\subsection{Cloud Computing}

Growers can use cloud facilities to access data from predictive analytics agencies so that they can find the right products based on their exact needs. Cloud computing offers growers a knowledge-based repository that contains valuable information and experience related to farming methods and equipment options available on the market. The scheme can be further extended to include access to consumer databases, supply chains, and billing systems to make it more active.

Obviously, cloud-based services offer ample opportunities but also bring new challenges. First, various sensors are being developed and utilized in smart farming, each with its unique data format and semantics. Second, most decision support systems are application-specific. On the other hand, farmers may need access to various systems for specific applications, such as soil monitoring. Considering these two situations, cloudbased decision support systems not only need to handle the diverse data and their formats, but they should also be able to configure these formats for various applications.

\subsection{Harvesting}

In the agriculture sector, harvesting is a crucial phase in the crop production process because this final stage determines crop yield and, eventually, the crop's performance. Regarding manpower, it is expected that the US faces USD 3.1 billion worth of crop losses each year due to manpower shortages [142]. Additionally, according to the United States Department of Agriculture (USDA), 14\% of total agricultural costs are spent on wages and labor, and as high as 39\% on some labor-intensive farms [143]. Considering the expense and manpower shortage issues at this stage, farm experts hope that the use of agricultural robotics technology will not only reduce manpower shortage but also provide flexible harvesting capabilities when required. Automatic fruit harvesting requires in-depth research on sophisticated sensors that can collect precise and unambiguous information about specific crops and fruits.

For example, strawberries are highly consumed fruits and can be purchased all year round. However, manpower, particularly during the packaging and harvesting stages, is a major factor for the high-level price of this fruit [144]. Because this fruit is mostly cultivated in the greenhouses system, the harvesting robot can reduce the production cost. A robot developed by Agrobot is capable of collecting strawberries along the field's strawberry plant rows and enhancing packaging through the operator [145]. For example, Agrobot's SW 6010 is a semi-automatic robot for semi-automatic strawberry picking. Tektu T-100 is a rechargeable electric strawberry harvester that operates multiple channels with a net-zero emission [144].

\section{Uses of UAVs in Agriculture Advancement}

Currently, the IoT plays an important role in several fields, such as the agriculture industry (e.g., fish and poultry). There is a limited communication network in the agricul- 
tural sector, including Wi-Fi and base stations, which decreases the coverage of internet technology. Advanced communication technologies are the worst in developing countries, which are the major hurdles and challenges for the implementation of the IoT in agriculture. Without a reliable communication infrastructure, the information collected using sensor devices is not transferred quickly for analysis in developing countries [146]. Under these circumstances, UAVs can provide an alternate option to gather information for data analysis and processing. Moreover, UAVs equipped with advanced thermal, multispectral, hyperspectral cameras, and wireless sensors can collect data from several hectares of agricultural lands in a short duration. Currently, the agriculture sector can obtain tremendous benefits by deploying UAVs to address several major and long-term issues. We highlight some important areas where UAVs have played a crucial role in assisting growers throughout the crop cycle globally [147].

\subsection{Soil and Water Analysis}

New technology such as UAVs can provide accurate data to examine soil and soil water before planting crops, which can help determine which crops are best suited for a particular land. In addition, it can provide information about the type of seed and how it can be grown under particular soils and environments [148].

\subsection{Planting}

Today, millions of acres are not cultivated worldwide due to the lack of appropriate manpower or human inaccessibility. The safety issue of the rough terrain is the major problem for not utilizing these areas for agricultural or forestry purposes. To this end, drone-based sowing methods are being established that can reduce sowing expenses by up to $85 \%$ [149]. Not only is it cost-effective, but it even expedites the planting because many newly formed drones can plant about 100,000 trees within one day [150]. These systems shoot pods comprise seed, which are essential nutrients required for plant growth. This technique is very effective for rough terrain; significantly, the success rate is more than $75 \%$ [151]. Because of the flexibility and success, the recommended drones can be excellent plantation systems worldwide $[152,153]$.

\subsection{Irrigation}

The benefit of using UAVs are twofold in irrigation applications. First, equipping drones with various cameras and sensors can support the identification of areas under water stress to quantify irrigation water requirements. Second, they can also be utilized to spray herbicides and pesticides accurately and water on crops, particularly in emergencies, which can save time [154-156]. Besides, UAVs can also be utilized to assess crop water stress [157]. Because of advanced UAVs, these can be applied as water-saving tools. UAVs use not only facilitate improving watering efficiency but also identify leaks in irrigation or possible water sinks, such as "JT20L-606" [158] and "AGRASMG-1" [159], which are specially developed UAVs that are currently being utilized to serve this purpose.

\subsection{Health Assessment of the Crops}

Scanning agriculture crops using infrared and visible (IR) light sensor technology mounted on the UAVs can recognize which farming plants may be infested via fungicide or bacteria. Detecting any such issues in advance helps prevent the disease from spreading to other crops or plant parts [160].

\subsection{Spraying Pesticides/Herbicides}

UAVs can be utilized to spray insecticides, pesticides, and herbicides on crops. Spraying applications will benefit current practices of spraying pesticides or herbicides across the entire farm that is usually not needed in most cases. If UAVs are used to spray the pesticides or herbicides, they can be directly sprayed on weeds or only concentrate on the disturbed area. It can be poured directly on weeds. Besides, since UAV spraying is highly 
targeted to the objects/plants or weeds, it can be configured and sprayed as required, reducing overall expenses. For UAVs, handling sudden environmental changes, such as wind direction, is problematic, mainly when spraying applications [160].

\subsection{Plant Species Detection/Identification}

Recently, UAVs have begun to identify plant species, particularly those that are very few on the planet. UAVs are the best tools for this task, as they can fly in very remote places with limited physical access. According to the National Tropical Botanical Garden (NTBG), Hawaiian calyx Hibiscadelphus woodii was found on a vertical cliff face using a drone, which was believed to have become extinct in 2009 [161,162]. Precision farming desperately requires spatial information on crop density when making decisions during several applications. Quantities and plant numbers not only reflect crop yields, but they can accurately assess outcomes and determine the fate of a crop. Gnädinger and Schmidhalter [163] counted corn plants digitally using drones. Additionally, Jin et al. [164] proposed a technique to use UAVs to evaluate wheat plants' density at the seedling phase and captured images using a Sony ILCE $\alpha 5100$ LRGB camera. Crop monitoring is a daunting task and is inefficient due to the large coverage area. Compared with satellite images used in the past, UAVs provide all farm results by providing real-time monitoring data, so they are further accurate and cost-effective. Microdrones' $+m$ accessory kit offers aerial imaging capabilities to monitor moisture content, crop nutrients status, and other essential factors $[165,166]$.

\section{Food Safety and Transportation}

The World Resources Institute's (WRI) Comprehensive Report on Future Food Demand, released in 2018, highlights the food industry's need to feed ten billion people before 2050. The statement aims for a five-course menu of solutions to decrease food waste and losses in the future [167]. Furthermore, the assumption is that reducing waste and loss of food by $25 \%$ by 2050 can decrease the food gap by $12 \%$, the land gap by $27 \%$, and the difference by which greenhouse gas emissions can be reduced by $15 \%$ [167]. For a better understanding, losses of food occurring along the food supply chain (from food production to consumption) at different geographical regions worldwide are depicted in Figure 5. The highest percentage of calories lost and wastage $(61 \%)$ in food consumption was observed in North America and Oceania, whereas the lowest (5\%) was observed in sub-Saharan Africa. In contrast, the lowest percentage of calories lost and wastage (23\%) in food production and handling was observed in North America and Oceania, whereas the highest (76\%) was observed in sub-Saharan Africa.

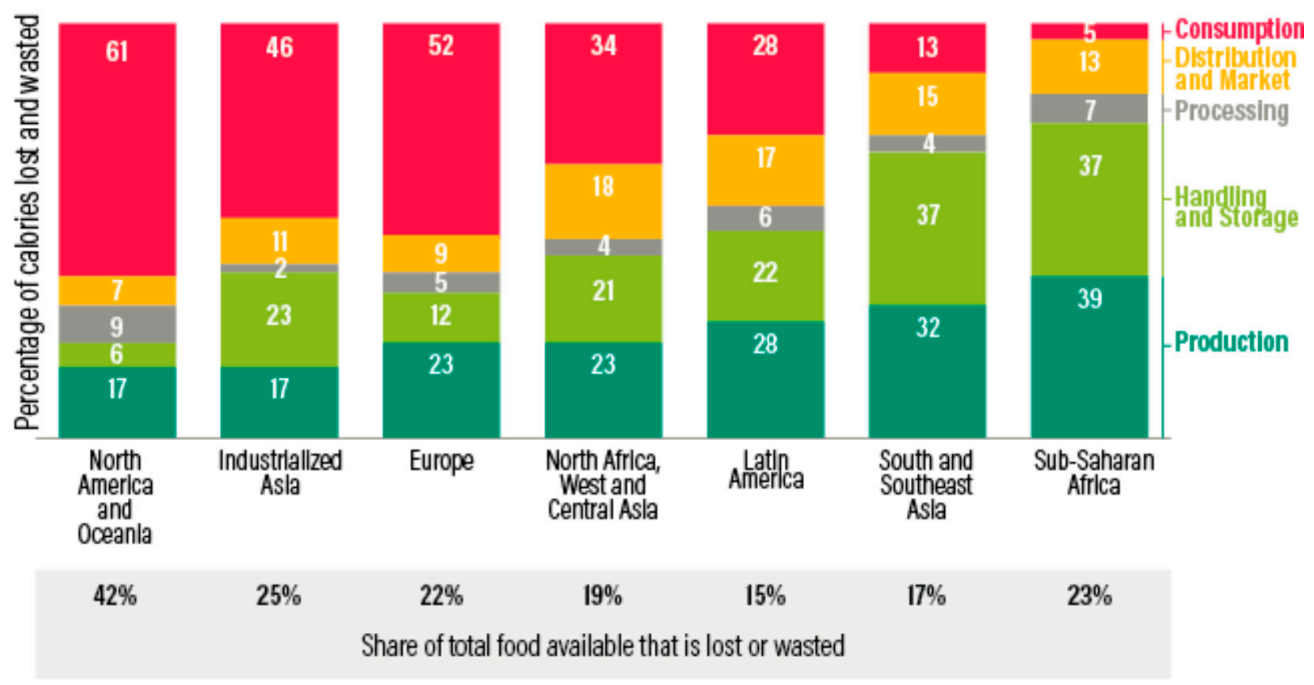

Figure 5. Losses of food occur along the food supply chain $[5,167]$. 
In addition to the WRI, the information released by the FAO of the UN is also shocking. It is projected that one-third of all food produced for humans globally wasted each year is worth USD 1 trillion $[168,169]$. Food waste in the US alone accounts for $1.3 \%$ of its gross domestic product [170]. Based on these numbers, it can be assumed that food wastage is critical in food industries, and such loss does not exist in non-food industries [171]. Even though food wastage worth USD 1 trillion has its economic value, more significantly, the impact of these losses on the environment is critical. For example, the water wasted on producing food that has never been consumed is the same as the water that can meet the water demand of all of Africa $[167,172,173]$. Today, all over the world, only $10 \%$ of perishable foods are properly well-preserved [174]. There is a massive opportunity to reduce food losses and better distribute food simply via realizing temperature-regulated transportation systems. Based on these facts, it can be concluded that enhancing food production is not enough to attain food safety. However, many useful actions are needed to obtain a better-skilled way of distributing existing food effectively. As shown in Figure 5, the IoT can monitor and maintain food quality at all stages of the entire supply chain from yield to consumption.

\subsection{Compliance}

The IoT can support the Hazard Analysis and Critical Control Point (HACCP) compliance, provide food security, and is an excellent monitoring program that continuously accumulates the temperature data in kitchen equipment and coolers. Its integration with the touch module is utilized to monitor the temperature in the cooler and the preparation chamber continuously [175].

\subsection{Laird Sentrius}

The battery-powered remote integrated sensor system takes full advantage of Bluetooth Low Energy (BLE) and Low Power Wide Area Network (LoRaWAN) connectivity. It is based on Nordic nRF51 silicon, Semtech SX1272, and offers an 868/915 MHz LoRaWAN option and provides high nRF51 performance at precise humidity temperature. The two most important families consist of RG1xx and RS1xx (multi-wireless gateways) to operate collectively to deliver cloud-based services. It is highly significant and needs cheap endpoint radios and other complex base stations to handle the network system compared with low-power wide-area network technology. If Sigfox network transmission is directed from the endpoint to the base station, communication will be better. Although it helps to have bidirectional capabilities, the power from the station to the endpoint is limited because it delivers lower downlink width than the uplink width.

\subsection{Tempreporter}

The HACCP is utilized to monitor temperature 24/7. Besides, it automatically records measurements. It also automatically fills the values in the report. The Health Product Regulatory Authority (HPRA) recommends HACCP to monitor the temperature. According to a Finistere Ventures report, as of 2018, global investment in AgTech was approximately USD 2 billion. Numerous assets are expected to cross these numbers in 2022. Considering the future needs of the IoT in agricultural applications, the advancement of the IoT is important. Table 5 lists some of the top global organizations with proposed AgTech initiatives, particularly in Internet technology-based agricultural solutions. 
Table 5. Key role of some of the technological applications regarding IoT in advanced agriculture.

\begin{tabular}{|c|c|c|}
\hline Organization & Initiatives and Vision & References \\
\hline Google & $\begin{array}{l}\text { In order to provide food heating systems, Google and the MIT Media Lab Open } \\
\text { Agriculture Initiative (Open } \mathrm{Ag}^{\mathrm{TM}} \text { ) proposed a vision for future agriculture and crops. To } \\
\text { give advanced cloud-based services in advanced agriculture the program (e.g., Food } \\
\text { Computer }{ }^{\mathrm{TM}} \text { equipment) and many open-source technologies in closed and } \\
\text { climate-controlled environments. They also proposed different initiatives, such as its } \\
\text { Climate Recipe Program, which proposed solutions based on the cross-correlation of plant } \\
\text { phenotypic responses with biological, environmental, and genetic variables. }\end{array}$ & [176] \\
\hline Microsoft & $\begin{array}{l}\text { Microsoft has begun to invest in advanced agriculture. The company started a five-year, } \\
\text { USD } 50 \text { million plan in } 2018 \text { named } \mathrm{Al} \text { for Earth. In this plan, Microsoft targets four key } \\
\text { areas for building a suitable future: agriculture, climate, water, and biodiversity. The } \\
\text { primary goal of the company is to use its expertise in cloud computing, artificial } \\
\text { intelligence (AI), and the internet to solve agricultural problems. }\end{array}$ & [177] \\
\hline Intel & $\begin{array}{l}\text { Infiswift is an IoT platform based on a high-performance Intel architecture that aims to } \\
\text { improve the efficiency of agricultural operations by providing connected services } \\
\text { throughout the agricultural ecosystem. }\end{array}$ & [5] \\
\hline Jasper, Cisco & $\begin{array}{l}\text { Jasper is part of Cisco and provides a cloud-based software platform for agribusiness IoT. } \\
\text { The platform is rapidly embracing IT services to realize advanced agriculture using } \\
\text { automation, real-time visibility, and remote diagnoses. }\end{array}$ & [178] \\
\hline $\begin{array}{l}\text { Watson, International } \\
\text { Business Machines } \\
\qquad(\text { IBM) }\end{array}$ & $\begin{array}{l}\text { Watson Decision is an AI-based service that delivers an agricultural platform designed to } \\
\text { use advanced equipment and IT to develop the sustainability, harvest, and value of } \\
\text { advanced agriculture. In this way, IBM uses its experience, data, and AI services to } \\
\text { support growers in making excellent decisions throughout the planting stage. }\end{array}$ & [179] \\
\hline $\begin{array}{l}\text { Hewlett Packard } \\
\text { Enterprise (HPE) }\end{array}$ & $\begin{array}{l}\text { Purdue University has begun to use wireless sensor innovation and the IoT to } \\
\text { revolutionize agricultural research; every day, different sensors, cameras, and different } \\
\text { types of manual input are used to capture essential data, all of which are processed and } \\
\text { evaluated in real-time. In order to effectively monitor food quality, Purdue cooperates } \\
\text { with HPE to integrate research, innovation, and technology such as cloud computing and } \\
\text { internet technology to transform into the latest practice of digital agriculture. }\end{array}$ & [180] \\
\hline Dell & $\begin{array}{l}\text { Dell has begun to introduce agricultural robots and machines equipped with advanced } \\
\text { machine learning and AI functions. The company has currently joined Aero-farms } \\
\text { (vertical agricultural power) to accelerate the provision of the IoT and data science } \\
\text { services for advanced agriculture. }\end{array}$ & [181] \\
\hline Qualcomm & $\begin{array}{l}\text { Qualcomm Ventures (QV) has been one of the leading wireless companies for the past } 15 \\
\text { years, and now QV considers AgTech to be one of the main investment areas for future } \\
\text { projects. They have recently established global partnerships with Strider (Brazilian Farm } \\
\text { Management Platform), Ninjacart (Indian Agricultural Comprehensive Trading Market), } \\
\text { and FarmEasy (Chinese Farm Data Platform), especially in Latin America Partnership } \\
\text { reveals the status of advanced agriculture. }\end{array}$ & {$[182,183]$} \\
\hline Hello, Tractor & $\begin{array}{l}\text { Hello, Tractor and IBM Research have established a blockchain-based platform AI that } \\
\text { pays special attention to African growers. The new technology giant co-founded by IBM } \\
\text { will jointly test the product this year. The cloud-based service, dubbed Digital Wallet, aims } \\
\text { to support the Hello Tractor business, which is dedicated to providing small-scale farmers } \\
\text { with technical equipment and analytical data to create advance agricultural ecosystems. }\end{array}$ & [184] \\
\hline Farm2050 & $\begin{array}{l}\text { According to Farm } 2050 \text {, worldwide food production has to be increased by } 70 \% \text { from the } \\
\text { current levels to meet the increased food demand for a population of approximately } 10 \\
\text { billion by } 2050 \text {. This is a major initiative for AgTech in the future, as } 25 \text { world-leading } \\
\text { organizations such as Google, Microsoft, Bayer, John Deere, and Pepsi cooperate with this } \\
\text { organization. Its rudimentary objective is to use new technologies to develop the future of } \\
\text { food by supporting AgTech entrepreneurs and start-ups. }\end{array}$ & [185] \\
\hline
\end{tabular}

\subsection{CCP Smart Label (RC4)}

The CCP asserts an integrated monitoring solution for the food retail industry and food services [5]. It automates the temperature environment to meet the protection and safety of food regulations for different foods. Besides, the temperature and other information are explained and viewed on the service provider's cloud platform via smartphones and web applications. 


\section{Current Challenges and Future Prospects}

In 2015, the UN developed strategies that help attain sustainable agricultural development by 2030. However, the latest statistical data issued by the WHO do not look favorable for sustainability. This plan shows that more than 800 million people globally face food shortages, which is one out of every nine people in the world [185]. To address these issues, the overall grain production needs to be increased. Additionally, cash crops need to be increased to meet industrial requirements such as rubber and cotton. Most significantly, the demand for bioenergy, such as ethanol, will also increase by 2030 .

This review outlines the main issues that agriculture would face by 2050. This review essentially addresses two main questions. How do the advanced technologies help to: (1) feed about 10 billion people? and (2) increase agricultural production without occupying more agricultural land? Moreover, these issues bring several challenges, such as the reduction in agricultural manpower, the decreasing arable land area, the shortage of water resources, the impact of climate change, etc. As the world shifts towards urbanization, not only is the population of rural areas declining, but it is also rapidly aging. As a result, young farmers are required to step up to take liability. Population imbalances and generational transfers will have a serious impact not only on the rural agricultural manpower but also on-farm management. Besides, while arable land is diminishing, many lands are only appropriate for select crops due to certain geographical and environmental constraints. Besides, climate change has begun to affect almost all crops. These variations are anticipated to intensify many existing long-term ecological difficulties, such as turf, floods, soil degradation, groundwater depletion, and more.

Compared with developed nations, more than $50 \%$ of the populations of developing nations are directly or indirectly involved in agriculture. Still, they are far behind developed countries in terms of quantity and quality. The population of developed countries, which is less than $2 \%$, is performing much better. This difference is evident because Australia, the US, and most European countries have adopted improved tools and methods. Over the past fifty years, they have adopted improved instruments and techniques to increase crop production. These differences demonstrate that advanced technology and sophisticated approaches make the farm more productive and ecologically sound.

It is expected that the future of agriculture will develop into a progressive sector when integrated systems appreciate artificial intelligence and big data capabilities. These integrated systems will combine several agricultural types of equipment, tools, and techniques applicable for various agricultural management from sowing to yield forecasting. Advanced machines, such as robots of agriculture, cloud computing, artificial intelligence, and big data, can usher in a different era of super-convergence in the farming sector. Here are crucial tools and techniques that need to be applied for sustainable agriculture in the future.

\subsection{Smartphone and the IoT}

Information communication technologies such as smartphones and the IoT can change agriculture in developing countries by facilitating access to markets and providing problemsolving information. These technologies can also bridge the rural-urban gap, including the next generation of growers. Most agricultural-related smartphone services in developing countries have provided simple functions due to the limitations of available delivery technologies [79-81]. Fast-moving smartphones and the IoT may soon change by giving many opportunities for developing complex services. Today, users can use a wide variety of devices to spread more complex information. Simultaneously, smartphones and the IoT have become increasingly popular and interconnected through expanded smartphone networks, allowing for the collection and processing of large amounts of data to help agricultural farming and the establishment of social networks for information exchange and learning.

This article discusses relevant knowledge and implications, but further study is required to assess how the latest tools and technologies can be practically used to support 
agriculture in developing nations. For example, what challenges exist and what is needed to eliminate them? The smartphone and IoT technology developers also need to ensure that their services continue to meet a wide range of user needs, rather than concentrating too much on new machinery that may not be available to limited resource underserved growers.

\subsection{The IoT and Wireless Sensors (IoTWS)}

Installing IoTWS appropriately across farmland can provide growers with the latest knowledge and information and enable them to change accordingly, which helps enhance crop yields. For sustainable agriculture, the IoT can be core and forefront for farming operations. This comprises the efficient use of electricity, water, transportation of crops, alerts for the maintenance and operation of agriculture machinery, and updated market prices. It can simplify and streamline these tasks by identifying crop requirements at each step. It has proven to be advanced and will provide farmers with unprecedented control over land and assets, thereby further changing our perceptions of various agricultural activities to maximize their efficiency and effectiveness. Besides, the upcoming Internet technology can be formed by significant improvements in wireless sensor networks and 5 th generation (5G) of smartphone communication technology, providing growers important updates in real-time and anywhere. Based on recent successes, by 2021, it is assessed that there will be more than 75 million internet technology-based devices working in the agriculture sector. Furthermore, the average farm is expected to produce 4.1 million data points regularly by 2050 [186].

\subsection{Communication}

The actual achievement of the IoT in farming depends mostly on increased connectivity. From a telecommunications perspective, connectivity and more value-added essential services have a vast perspective and can significantly affect the whole chain [187]. Almost all telecommunication operators worldwide provide connectivity facilities, but such public services represent only a small portion of the total advanced agriculture market. Given its worth, especially in remote regions, smartphone operators must offer a range of the latest services to fulfill growers' needs. Accepting the truth that most people in the community are not highly educated, and, therefore, they do not fully understand new technologies, operators must give end-to-end resolutions, not only connectivity. Therefore, it will enhance the market share of smartphones and telecommunication operators. Peters [119,188] considered 23 experiments mainly in developing countries and concluded that cellular services and smartphone technology had brought a bright future to small farmers capable of increasing yields. It is very important to give crucial connectivity in the agriculture sector.

\subsection{Drones and Other Robots}

Farmers and growers use UAVs to evaluate crop growth and monitor biodiversity and ecological landscape features [189]. Additionally, considering the rugged farmland, particularly when the farmers have to grow crops on the rugged landscape, UAVs can effectively be used for water spraying and other pesticides. Compared with traditional machinery, with the same propose, robots and drones have confirmed they are worth spraying with haste and accuracy. With the latest improvements in swarm technology and task-based control, multiple sets of robots and drones armed with diverse devices such as 3D cameras can work together to give growers inclusive land management capabilities. In addition to drones, robotics in the agricultural sector have increased productivity and brought higher crop production. Robots, for weeding and spraying, are decreasing the use of pesticides. 


\subsection{Machine Learning and Artificial Intelligence}

Machine learning (ML) and artificial intelligence (AI) are utilized to mine data for trend analysis. For example, in agriculture, ML/AI is applied to explore which genes are very appropriate to produce high-yield crops. This gives farmers worldwide better varieties of seeds that are suitable for the location and climate. On the other hand, ML/AI algorithms have demonstrated which goods are in great demand and which goods are not accessible in the market. Thus, for growers, this gives valuable information for upcoming farming. The latest advances in ML/AI will make it possible for growers to correctly classify their crop products and eliminate fewer advantageous products before they start planting.

\subsection{Energy Consumption, Renewable Energy, Microgrid, and Smart Grid}

Despite technological advances in agriculture, advanced farming still faces many issues that hinder the extended use of the IoT. One of the notable issues regarding energy/power consumption is that advanced agriculture needs extensive energy. The major problems for a large amount of energy consumption include the long-term deployment of sensors, repeated transmission of sensing information by general packet radio service, and GPS use. Traditionally, growers in rural areas have randomly bought and used renewable energy at high prices, which has largely restricted their use for advanced agriculture. However, to resolve the energy problem, in the long run, an in-depth analysis of the power source (such as remote information communication) can address the problem to some extent. In addition, smart grids and microgrids enable the perfect integration of distributed energy sources (DER), so they have attracted farmers' adoption. The advent of smart meters has made farmers more confident in investing in DER, particularly because farmers can select full excess electricity to the grid. If a continuous energy source is not available for users in remote areas, alternative rechargeable devices or thermal/electrical/mechanical energy storage systems should be available for them to use. Current advances in energy storage apparatus, heating system, and electricity will further make DER smarter to growers. They will be able to store energy and use the heat created via heating and cooling when required $[190,191]$. Moreover, requirements of healthy investment and public awareness are two other obstacles to the success of these resolutions.

\subsection{Vertical Farming and Hydroponics}

In addition to adopting advanced technologies, new agricultural practices are also critical to overcoming geographical and resource constraints. While arable land is decreasing, it is assumed that 3 million people worldwide have shifted to urban areas, putting more stress on existing limited city resources [192]. Contemplating this quick migration, it is projected that before $2030,60 \%$ of the world population will rely on urban areas, and these figures are expected to increase to $68 \%$ before $2050[3,193]$. Considering these two issues, food production may be disastrous as soon as current agricultural practices are concerned. VF solves these problems because it can meet the challenges of shortage of water and land management, and at the same time, it seems very appropriate for adoption near urban areas or cities. At least in some parts of the world, VF is depicted as the solution to food shortages and shrinking arable land. Besides, hydroponics can play a very important role, as it greatly reduces the need for space and water. The rapid growth of technologies has promoted water and nutrient efficient farming, such as VF, making it more attractive to farmers. Alongside hydroponics and VF, the latest and improved solutions are needed to boost the arable land without disturbing forests and natural animal habitats. To accomplish this, it is necessary to focus on the desert, because it covers a third of the Earth's land surface. With Norwegian and Chinese companies/experts working in the deserts of Dubai, Qatar, Jordan, and China, solutions have begun to be developed [194-196]. The existence of advanced technologies, such as the IoT, is critical to achieving this target. 


\section{Conclusions}

Due to the continuous increase in the world population, the demand for food increases. Consequently, forests and arable lands are changing into urban landscapes. In the context of shrinking arable land area, highly efficient and advanced technologies need to meet a growing world population's food demands. At present, people can easily see the development of advanced approaches to enhance crop yield and improve other agriculture measures. Some people with a lack of innovative spirit and technology take agriculture as a profession. Although they have partnerships and collaboration among suppliers, farmers, retailers, and buyers, there is a gap between them for proper communication. To fill this gap, there is an urgent need for innovative and advanced technologies. This review covers multiple aspects of technology used in agriculture and enlightens the key role of advanced technologies, particularly the IoT, to advance agriculture to meet future expectations. Moreover, other advanced technologies, such as UAVs, remote and ground sensors, communication technologies, and cloud computing, are needed for sustainable agriculture. This review provides deeper insights into the latest research findings. Based on all of the above important information, it is concluded that there is a dire need for crop production and improvement. However, implementing these advanced and innovative technologies, such as the IoT, are genuinely indeed not optional. By adopting these advanced technologies, farmers will improve their agricultural resources and practices. The advancement in such advanced technologies will pave the path for sustainable agriculture.

Author Contributions: N.K.; Data curation. N.K., R.L.R. and M.I.; Investigation. N.K., R.L.R. and M.I.; Methodology. N.K., G.R.S., M.I., M.K., S.I.; Software. N.K., R.L.R. and M.I.; Supervision. N.K., R.L.R., G.R.S., M.I., M.K. and S.I.; Visualization. N.K., R.L.R., M.I. and S.I.; Writing-original draft. N.K., R.L.R. and M.I.; Writing—review \& editing. R.L.R. and G.R.S.; Funding acquisition. All authors have read and agreed to the published version of the manuscript.

Funding: This research was partially supported by the Evans-Allen project of the United States Department of Agriculture (USDA), National Institute of Food and Agriculture.

Institutional Review Board Statement: Not applicable.

Informed Consent Statement: Not applicable.

Acknowledgments: This work was partially supported by the Evans-Allen project of the United States Department of Agriculture (USDA), National Institute of Food and Agriculture.

Conflicts of Interest: The authors declare that they have no conflict of interest.

\section{References}

1. Union, U. World Population Projected to Reach 9.8 Billion in 2050, and 11.2 Billion in 2100; UN DESA: New York, NY, USA, 2017.

2. McNabb, D.E. The population growth barrier. In Global Pathways to Water Sustainability; Springer: Berlin/Heidelberg, Germany, 2019; pp. 67-81.

3. United Nations Department of Economic and Social Affairs. $68 \%$ of the World Population Projected to Live in Urban Areas by 2050, Says UN; United Nations Department of Economic and Social Affairs: New York, NY, USA, 2018.

4. Zhang, X.; Davidson, E.A. Improving nitrogen and water management in crop production on a national scale. In Proceedings of the AGU Fall Meeting, Washington, DC, USA, 10-14 December 2018; p. B22B-01.

5. Ayaz, M.; Ammad-Uddin, M.; Sharif, Z.; Mansour, A.; Aggoune, E.-H.M. Internet-of-Things (IoT)-Based Smart Agriculture: Toward Making the Fields Talk. IEEE Access 2019, 7, 129551-129583. [CrossRef]

6. Tripathi, A.D.; Mishra, R.; Maurya, K.K.; Singh, R.B.; Wilson, D.W. Estimates for world population and global food availability for global health. In The Role of Functional Food Security in Global Health; Elsevier: Amsterdam, The Netherlands, 2019; pp. 3-24.

7. Elder, M.; Hayashi, S. A regional perspective on biofuels in Asia. In Biofuels and Sustainability; Springer: Berlin/Heidelberg, Germany, 2018; pp. 223-246.

8. Hassan, Q.F. Internet of Things A to Z: Technologies and Applications; John Wiley \& Sons: Hoboken, NJ, USA, 2018.

9. Navulur, S.; Prasad, M.G. Agricultural management through wireless sensors and internet of things. Int. J. Electr. Comput. Eng. 2017, 7, 3492. [CrossRef]

10. Sisinni, E.; Saifullah, A.; Han, S.; Jennehag, U.; Gidlund, M. Industrial internet of things: Challenges, opportunities, and directions. IEEE Trans. Ind. Inform. 2018, 14, 4724-4734. [CrossRef] 
11. Ayaz, M.; Ammad-Uddin, M.; Baig, I. Wireless sensor's civil applications, prototypes, and future integration possibilities: A review. IEEE Sens. J. 2017, 18, 4-30. [CrossRef]

12. Lin, J.; Yu, W.; Zhang, N.; Yang, X.; Zhang, H.; Zhao, W. A survey on internet of things: Architecture, enabling technologies, security and privacy, and applications. IEEE Internet Things J. 2017, 4, 1125-1142. [CrossRef]

13. Shi, X.; An, X.; Zhao, Q.; Liu, H.; Xia, L.; Sun, X.; Guo, Y. State-of-the-art internet of things in protected agriculture. Sensors 2019, 19, 1833. [CrossRef]

14. Khan, N.; Siddiqui, B.N.; Khan, N.; Ismail, S. The Internet of Thing in Sustainable Agriculture. Artech J. Res. Stud. Agric. Sci. 2020, 2, 12-15.

15. Demestichas, K.; Peppes, N.; Alexakis, T. Survey on Security Threats in Agricultural IoT and Smart Farming. Sensors 2020, 20, 6458. [CrossRef]

16. Bonneau, V.; Copigneaux, B.; Probst, L.; Pedersen, B.; Industry 4.0 in Agriculture: Focus on IoT Aspects. European Commission, Digital Transformation Monitor. Available online: https://ec.europa.eu/growth/tools-databases/dem/monitor/content/ industry-40-agriculture-focus-iot-aspects (accessed on 10 July 2017).

17. King, T.; Cole, M.; Farber, J.M.; Eisenbrand, G.; Zabaras, D.; Fox, E.M.; Hill, J.P. Food safety for food security: Relationship between global megatrends and developments in food safety. Trends Food Sci. Technol. 2017, 68, 160-175. [CrossRef]

18. Chung, S.-S.; Wong, C.K. Regulatory and Policy Control on Food Safety in China; BMJ Publishing Group Ltd.: London, UK, 2013.

19. Khanna, A.; Kaur, S. Evolution of Internet of Things (IoT) and its significant impact in the field of Precision Agriculture. Comput. Electr. Agric. 2019, 157, 218-231. [CrossRef]

20. Tzounis, A.; Katsoulas, N.; Bartzanas, T.; Kittas, C. Internet of Things in agriculture, recent advances and future challenges. Biol. Eng. 2017, 164, 31-48. [CrossRef]

21. Dinkins, C.P.; Jones, C. Interpretation of Soil Test Reports for Agriculture; MT200702AG, Montana State University Extension: Bozeman, MT, USA, 2013.

22. Saiz-Rubio, V.; Rovira-Más, F. From smart farming towards agriculture 5.0: A review on crop data management. Agronomy 2020, 10, 207. [CrossRef]

23. Shafi, U.; Mumtaz, R.; García-Nieto, J.; Hassan, S.A.; Zaidi, S.A.R.; Iqbal, N. Precision agriculture techniques and practices: From considerations to applications. Sensors 2019, 19, 3796. [CrossRef] [PubMed]

24. Villa-Henriksen, A.; Edwards, G.T.; Pesonen, L.A.; Green, O.; Sørensen, C.A.G. Internet of Things in arable farming: Implementation, applications, challenges and potential. Biol. Eng. 2020, 191, 60-84. [CrossRef]

25. Navarro, E.; Costa, N.; Pereira, A. A systematic review of IoT solutions for smart farming. Sensors 2020, 20, 4231. [CrossRef] [PubMed]

26. Talavera, J.M.; Tobón, L.E.; Gómez, J.A.; Culman, M.A.; Aranda, J.M.; Parra, D.T.; Quiroz, L.A.; Hoyos, A.; Garreta, L.E. Review of IoT applications in agro-industrial and environmental fields. Comput. Electr. Agric. 2017, 142, 283-297. [CrossRef]

27. Martínez-Fernández, J.; González-Zamora, A.; Sánchez, N.; Gumuzzio, A.; Herrero-Jiménez, C. Satellite soil moisture for agricultural drought monitoring: Assessment of the SMOS derived Soil Water Deficit Index. Rem. Sens. Environ. 2016, 177, 277-286. [CrossRef]

28. Vågen, T.-G.; Winowiecki, L.A.; Tondoh, J.E.; Desta, L.T.; Gumbricht, T. Mapping of soil properties and land degradation risk in Africa using MODIS reflectance. Geoderma 2016, 263, 216-225. [CrossRef]

29. Ray, R.L.; Fares, A.; He, Y.; Temimi, M. Evaluation and inter-comparison of satellite soil moisture products using in situ observations over Texas, US. Water 2017, 9, 372. [CrossRef]

30. Devaux, A.; Kromann, P.; Ortiz, O. Potatoes for sustainable global food security. Potato Res. 2014, 57, 185-199. [CrossRef]

31. Motoshita, M.; Ono, Y.; Pfister, S.; Boulay, A.-M.; Berger, M.; Nansai, K.; Tahara, K.; Itsubo, N.; Inaba, A. Consistent characterisation factors at midpoint and endpoint relevant to agricultural water scarcity arising from freshwater consumption. Int. J. Life Cycle Assess. 2018, 23, 2276-2287. [CrossRef]

32. Chen, T. Implementing Efficient and Multi-Hop Image Acquisition in Remote Monitoring IoT Systems Using LoRa Technology; University of Saskatchewan: Saskatoon, SK, Canada, 2019.

33. Li, J.; Liu, Y.; Xie, J.; Li, M.; Sun, M.; Liu, Z.; Jiang, S. A Remote Monitoring and Diagnosis Method Based on Four-Layer IoT Frame Perception. IEEE Access 2019, 7, 144324-144338. [CrossRef]

34. Dittmar, H.; Drach, M.; Vosskamp, R.; Trenkel, M.E.; Gutser, R.; Steffens, G. Fertilizers, 2. Types. In Ullmann's Encyclopedia of Industrial Chemistry; Wiley-VCH: Weinheim, Germany, 2000.

35. Smith, P.; Bustamante, M.; Ahammad, H.; Clark, H.; Dong, H.; Elsiddig, E.A.; Haberl, H.; Harper, R.; House, J.; Jafari, M. Agriculture, forestry and other land use (AFOLU). In Climate Change 2014: Mitigation of Climate Change. Contribution of Working Group III to the Fifth Assessment Report of the Intergovernmental Panel on Climate Change; Cambridge University Press: Cambridge, UK, 2014; pp. 811-922.

36. Lavanya, G.; Rani, C.; Ganeshkumar, P. An automated low cost IoT based Fertilizer Intimation System for smart agriculture. Sustain. Comput. Inform. Syst. 2019. [CrossRef]

37. Waskom, R.; Bauder, T.; Pearson, R. Best management practices for agricultural pesticide use. In Bulletin (Colorado State University. Extension); XCM-177; Colorado State University: Fort Collins, CO, USA, 1995.

38. Kim, S.; Lee, M.; Shin, C. IoT-based strawberry disease prediction system for smart farming. Sensors 2018, 18, 4051. [CrossRef] 
39. Venkatesan, R.; Kathrine, G.J.W.; Ramalakshmi, K. Internet of Things Based Pest Management Using Natural Pesticides for Small Scale Organic Gardens. J. Comput. Theoret. Nanosci. 2018, 15, 2742-2747. [CrossRef]

40. Kalachev, E. Exporting Technology to the Russian Agriculture Market. Bachelor's Thesis, JAMK University of Applied Sciences, Jyväskylä, Finland, 16 May 2016.

41. Oberti, R.; Marchi, M.; Tirelli, P.; Calcante, A.; Iriti, M.; Tona, E.; Hočevar, M.; Baur, J.; Pfaff, J.; Schütz, C. Selective spraying of grapevines for disease control using a modular agricultural robot. Biol. Eng. 2016, 146, 203-215. [CrossRef]

42. Stein, K.; Coulibaly, D.; Stenchly, K.; Goetze, D.; Porembski, S.; Lindner, A.; Konaté, S.; Linsenmair, E.K. Bee pollination increases yield quantity and quality of cash crops in Burkina Faso, West Africa. Sci. Rep. 2017, 7, 1-10. [CrossRef]

43. Wietzke, A.; Westphal, C.; Gras, P.; Kraft, M.; Pfohl, K.; Karlovsky, P.; Pawelzik, E.; Tscharntke, T.; Smit, I. Insect pollination as a key factor for strawberry physiology and marketable fruit quality. Agric. Ecol. Environ. 2018, 258, 197-204. [CrossRef]

44. Chung, S.-O.; Choi, M.-C.; Lee, K.-H.; Kim, Y.-J.; Hong, S.-J.; Li, M. Sensing technologies for grain crop yield monitoring systems: A review. J. Biol. Eng. 2016, 41, 408-417. [CrossRef]

45. Manfrini, L.; Pierpaoli, E.; Zibordi, M.; Morandi, B.; Muzzi, E.; Losciale, P.; Grappadelli, L.C. Monitoring strategies for precise production of high quality fruit and yield in Apple in Emilia-Romagna. Chem. Eng. Trans. 2015, 44, 301-306.

46. Benincasa, P.; Antognelli, S.; Brunetti, L.; Fabbri, C.A.; Natale, A.; Sartoretti, V.; Modeo, G.; Guiducci, M.; Tei, F.; Vizzari, M. Reliability of NDVI derived by high resolution satellite and UAV compared to in-field methods for the evaluation of early crop N status and grain yield in Wheat. Exp. Agric. 2018, 54, 604-622. [CrossRef]

47. Ihtisham, M.; Liu, S.; Shahid, M.O.; Khan, N.; Lv, B.; Sarraf, M.; Chen, Q. The Optimized N, P, and K Fertilization for Bermudagrass Integrated Turf Performance during the Establishment and Its Importance for the Sustainable Management of Urban Green Spaces. Sustainability 2020, 12, 10294. [CrossRef]

48. Khan, N.; Medlock, G.; Graves, S.; Anwar, S. GPS guided Autonomous Navigation of a Small Agricultural Robot with Automated Fertilizing System, 0148-7191; SAE Technical Paper; SAE: Warrendale, PA, USA, 2018.

49. Raut, R.; Varma, H.; Mulla, C.; Pawar, V.R. Soil Monitoring, Fertigation, and Irrigation System Using IoT for Agricultural Application. In Intelligent Communication and Computational Technologies; Springer: Berlin/Heidelberg, Germany, 2018; pp. 67-73.

50. González-Briones, A.; Castellanos-Garzón, J.A.; Mezquita Martín, Y.; Prieto, J.; Corchado, J.M. A framework for knowledge discovery from wireless sensor networks in rural environments: A crop irrigation systems case study. Wirel. Commun. Mob. Comput. 2018, 2018, 1-4. [CrossRef]

51. Villarrubia, G.; Paz, J.F.D.; Iglesia, D.H.; Bajo, J. Combining multi-agent systems and wireless sensor networks for monitoring crop irrigation. Sensors 2017, 17, 1775. [CrossRef]

52. Neto, A.J.S.; Zolnier, S.; de Carvalho Lopes, D. Development and evaluation of an automated system for fertigation control in soilless tomato production. Comput. Electr. Agric. 2014, 103, 17-25. [CrossRef]

53. Ihtisham, M.; Fahad, S.; Luo, T.; Larkin, R.M.; Yin, S.; Chen, L. Optimization of nitrogen, phosphorus, and potassium fertilization rates for overseeded perennial ryegrass turf on dormant bermudagrass in a transitional climate. Front. Plant Sci. $2018,9,487$. [CrossRef] [PubMed]

54. Bruns, H.A. Southern corn leaf blight: A story worth retelling. Agric. J. 2017, 109, 1218-1224. [CrossRef]

55. Pohanish, R.P. Sittig's Handbook of Pesticides and Agricultural Chemicals; William Andrew: Norwich, NY, USA, $2014 ;$ p. 1006.

56. Torbick, N.; Chowdhury, D.; Salas, W.; Qi, J. Monitoring rice agriculture across Myanmar using time series Sentinel-1 assisted by Landsat-8 and PALSAR-2. Remote Sens. 2017, 9, 119. [CrossRef]

57. Wang, Z.; Walsh, K.B.; Verma, B. On-tree mango fruit size estimation using RGB-D images. Sensors 2017, 17, 2738. [CrossRef]

58. Udomkun, P.; Nagle, M.; Argyropoulos, D.; Mahayothee, B.; Müller, J. Multi-sensor approach to improve optical monitoring of papaya shrinkage during drying. J. Food Eng. 2016, 189, 82-89. [CrossRef]

59. The FarmTRX Moisture Sensor Adds Moisture Capability to Your FarmTRX Yield Monitor. 2019. Available online: https: / / www.farmtrx.com/ (accessed on 15 April 2019).

60. Pimentel, D.; Burgess, M. Soil erosion threatens food production. Agriculture 2013, 3, 443-463. [CrossRef]

61. Benke, K.; Tomkins, B. Future food-production systems: Vertical farming and controlled-environment agriculture. Sustain. Sci. Pract. Policy 2017, 13, 13-26. [CrossRef]

62. Nishimura, T.; Okuyama, Y.; Matsushita, A.; Ikeda, H.; Satoh, A. A compact hardware design of a sensor module for hydroponics. In Proceedings of the 2017 IEEE 6th Global Conference on Consumer Electronics (GCCE), Nagoya, Japan, 24-27 October 2017; pp. 1-4.

63. Tripodi, P.; Massa, D.; Venezia, A.; Cardi, T. Sensing technologies for precision phenotyping in vegetable crops: Current status and future challenges. Agronomy 2018, 8, 57. [CrossRef]

64. Sarraf, M.; Kataria, S.; Taimourya, H.; Santos, L.O.; Menegatti, R.D.; Jain, M.; Liu, S. Magnetic field (MF) applications in plants: An overview. Plants 2020, 9, 1139. [CrossRef] [PubMed]

65. Zhou, J.; Reynolds, D.; Websdale, D.; Le Cornu, T.; Gonzalez-Navarro, O.; Lister, C.; Orford, S.; Laycock, S.; Finlayson, G.; Stitt, T. CropQuant: An automated and scalable field phenotyping platform for crop monitoring and trait measurements to facilitate breeding and digital agriculture. BioRxiv 2017, 161547. [CrossRef]

66. bin Ismail, M.I.H.; Thamrin, N.M. IoT implementation for indoor vertical farming watering system. In Proceedings of the 2017 International Conference on Electrical, Electronics and System Engineering (ICEESE), Kanazawa, Japan, 9-10 November 2017; pp. 89-94. 
67. Siregar, B.; Efendi, S.; Pranoto, H.; Ginting, R.; Andayani, U.; Fahmi, F. Remote monitoring system for hydroponic planting media. In Proceedings of the 2017 International Conference on ICT For Smart Society (ICISS), Tangerang, Indonesia, 18-19 September 2017; pp. 1-6.

68. Liang, J.-Y.; Chien, Y.-H. Effects of feeding frequency and photoperiod on water quality and crop production in a tilapia-water spinach raft aquaponics system. Int. Biodeterior. Biodegrad. 2013, 85, 693-700. [CrossRef]

69. Ibayashi, H.; Kaneda, Y.; Imahara, J.; Oishi, N.; Kuroda, M.; Mineno, H. A reliable wireless control system for tomato hydroponics. Sensors 2016, 16, 644. [CrossRef] [PubMed]

70. Theopoulos, A.; Boursianis, A.; Koukounaras, A.; Samaras, T. Prototype wireless sensor network for real-time measurements in hydroponics cultivation. In Proceedings of the 2018 7th International Conference on Modern Circuits and Systems Technologies (MOCAST), Thessaloniki, Greece, 7-9 May 2018; pp. 1-4.

71. Kong, Q.; Chen, H.; Mo, Y.-L.; Song, G. Real-time monitoring of water content in sandy soil using shear mode piezoceramic transducers and active sensing-A feasibility study. Sensors 2017, 17, 2395. [CrossRef]

72. Kumar, R.; Zhang, X.; Wang, W.; Khan, R.U.; Kumar, J.; Sharif, A. A multimodal malware detection technique for Android IoT devices using various features. IEEE Access 2019, 7, 64411-64430. [CrossRef]

73. Gasso-Tortajada, V.; Ward, A.J.; Mansur, H.; Brøchner, T.; Sørensen, C.G.; Green, O. A novel acoustic sensor approach to classify seeds based on sound absorption spectra. Sensors 2010, 10, 10027-10039. [CrossRef] [PubMed]

74. Khan, N.; Ismail, S.; Wali, A.; Kazim, R.; Azam, T. The influence of information communication technology development on income inequality. Artech J. Curr. Bus. Financ. Aff. 2020, 11, 18.

75. Alfian, G.; Syafrudin, M.; Rhee, J. Real-time monitoring system using smartphone-based sensors and nosql database for perishable supply chain. Sustainability 2017, 9, 2073. [CrossRef]

76. Pongnumkul, S.; Chaovalit, P.; Surasvadi, N. Applications of smartphone-based sensors in agriculture: A systematic review of research. J. Sens. 2015, 95308. [CrossRef]

77. Flor, A.G.; Cisneros, A.J. e-Agriculture. Int. Encycl. Digit. Commun. Soc. 2015, 9999, 1-6.

78. Omran, E.-S.E.; Negm, A.M. Smart Sensing System for Precision Agriculture. In Technological and Modern Irrigation Environment in Egypt; Springer: Berlin/Heidelberg, Germany, 2020; pp. 77-105.

79. Wyche, S.; Steinfield, C. Why don't farmers use cell phones to access market prices? Technology affordances and barriers to market information services adoption in rural Kenya. Inf. Technol. Dev. 2016, 22, 320-333. [CrossRef]

80. Baumüller, H. Agricultural Innovation and Service Delivery through Mobile Phones: Analyses in Kenya. Ph.D. Thesis, Universitäts-und Landesbibliothek Bonn, Bonn, Germany, 2015; p. 156.

81. Barnett, I.; Batchelor, S.; Gilligan, D.; Haddad, L.; Hidrobo, M.; Ledlie, N.; Palloni, G.; Scott, N.; Shyam, T. External Evaluation of Mobile Phone Technology-Based Nutrition and Agriculture Advisory Services in Africa and South Asia; IFPRI: Washington, DC, USA, 2017.

82. Gilligan, D.O.; Hidrobo, M.; Palloni, G.; Tambet, H. External Evaluation of Mobile Phone Technology-Based Nutrition and Agriculture Advisory Services in Africa and South Asia: Mobile Phones, Nutrition, and Health in Tanzania: Quantitative Endline Report; IFPRI: Washington, DC, USA, 2020.

83. Minkoua Nzie, J.; Bidogeza, J.-C.; Azinwi Ngum, N. Mobile phone use, transaction costs, and price: Evidence from rural vegetable farmers in Cameroon. J. Afr. Bus. 2018, 19, 323-342. [CrossRef]

84. Yu, Q.; Shi, Y.; Tang, H.; Yang, P.; Xie, A.; Liu, B.; Wu, W. eFarm: A tool for better observing agricultural land systems. Sensors 2017, 17, 453. [CrossRef]

85. Işık, M.F.; Sönmez, Y.; Yılmaz, C.; Özdemir, V.; Yılmaz, E.N. Precision irrigation system (PIS) using sensor network technology integrated with IOS/Android application. Appl. Sci. 2017, 7, 891. [CrossRef]

86. Guler, E.; Yilmaz Sengel, T.; Gumus, Z.P.; Arslan, M.; Coskunol, H.; Timur, S.; Yagci, Y. Mobile phone sensing of cocaine in a lateral flow assay combined with a biomimetic material. Anal. Chem. 2017, 89, 9629-9632. [CrossRef] [PubMed]

87. Baumüller, $\mathrm{H}$. The little we know: An exploratory literature review on the utility of mobile phone-enabled services for smallholder farmers. J. Int. Dev. 2018, 30, 134-154. [CrossRef]

88. Debauche, O.; Mahmoudi, S.; Andriamandroso, A.L.H.; Manneback, P.; Bindelle, J.; Lebeau, F. Cloud services integration for farm animals' behavior studies based on smartphones as activity sensors. J. Ambient Intell. Hum. Comput. 2019, 10, 4651-4662. [CrossRef]

89. Wan, X.; Cui, J.; Jiang, X.; Zhang, J.; Yang, Y.; Zheng, T. Smartphone based hemispherical photography for canopy structure measurement. In Proceedings of the 2017 International Conference on Optical Instruments and Technology: Optoelectronic Measurement Technology and Systems, Beijing, China, 28-30 October 2017; p. 106210Q.

90. Frommberger, L.; Schmid, F.; Cai, C. Micro-mapping with smartphones for monitoring agricultural development. In Proceedings of the 3rd ACM Symposium on Computing for Development, Bangalore, India, 11-12 January 2013; pp. 1-2.

91. Andriamandroso, A.L.H.; Lebeau, F.; Beckers, Y.; Froidmont, E.; Dufrasne, I.; Heinesch, B.; Dumortier, P.; Blanchy, G.; Blaise, Y.; Bindelle, J. Development of an open-source algorithm based on inertial measurement units (IMU) of a smartphone to detect cattle grass intake and ruminating behaviors. Comput. Electr. Agric. 2017, 139, 126-137. [CrossRef]

92. Azam, M.M.; Rosman, S.; Mustaffa, M.; Mullisi, S.S.; Wahy, H.; Jusoh, M.; Ali, M.M. Hybrid water pump system for hilly agricultural site. In Proceedings of the 2016 7th IEEE Control and System Graduate Research Colloquium (ICSGRC), Shah Alam, Malaysia, 8 August 2016; pp. 109-114. 
93. Herrick, J.E.; Beh, A.; Barrios, E.; Bouvier, I.; Coetzee, M.; Dent, D.; Elias, E.; Hengl, T.; Karl, J.W.; Liniger, H. The land-potential knowledge system (LandPKS): Mobile apps and collaboration for optimizing climate change investments. Ecosyst. Health Sustain. 2016, 2, e01209. [CrossRef]

94. Orlando, F.; Movedi, E.; Coduto, D.; Parisi, S.; Brancadoro, L.; Pagani, V.; Guarneri, T.; Confalonieri, R. Estimating leaf area index (LAI) in vineyards using the PocketLAI smart-app. Sensors 2016, 16, 2004. [CrossRef]

95. Sopegno, A.; Calvo, A.; Berruto, R.; Busato, P.; Bocthis, D. A web mobile application for agricultural machinery cost analysis. Comput. Electr. Agric. 2016, 130, 158-168. [CrossRef]

96. Bueno-Delgado, M.V.; Molina-Martínez, J.M.; Correoso-Campillo, R.; Pavón-Mariño, P. Ecofert: An Android application for the optimization of fertilizer cost in fertigation. Comput. Electr. Agric. 2016, 121, 32-42. [CrossRef]

97. Jordan, R.; Eudoxie, G.; Maharaj, K.; Belfon, R.; Bernard, M. AgriMaps: Improving site-specific land management through mobile maps. Comput. Electr. Agric. 2016, 123, 292-296. [CrossRef]

98. Freebairn, D.; Robinson, B.; McClymont, D.; Raine, S.; Schmidt, E.; Skowronski, V.; Eberhard, J. SoilWaterApp-monitoring soil water made easy. In Proceedings of the 18th Australian Society of Agronomy Conference, Ballarat, Australia, 24-28 September 2017.

99. Ferguson, J.C.; Chechetto, R.G.; O’Donnell, C.C.; Fritz, B.K.; Hoffmann, W.C.; Coleman, C.E.; Chauhan, B.S.; Adkins, S.W.; Kruger, G.R.; Hewitt, A.J. Assessing a novel smartphone application-SnapCard, compared to five imaging systems to quantify droplet deposition on artificial collectors. Comput. Electr. Agric. 2016, 128, 193-198. [CrossRef]

100. Scholz, M. Enhancing adoption of integrated weed management-an Australian farmer's perspective. Outlooks Pest Manag. 2018, 29, 66-69. [CrossRef]

101. Suen, R.C.L.; Chang, K.T.; Wan, M.P.-H.; Ng, Y.C.; Tan, B.C. Interactive experiences designed for agricultural communities. In CHI'14 Extended Abstracts on Human Factors in Computing Systems; Association for Computing Machinery: New York, NY, USA, 2014; pp. 551-554.

102. Pérez-Castro, A.; Sánchez-Molina, J.; Castilla, M.; Sánchez-Moreno, J.; Moreno-Úbeda, J.; Magán, J. cFertigUAL: A fertigation management app for greenhouse vegetable crops. Agric. Water Manag. 2017, 183, 186-193. [CrossRef]

103. Masek, P.; Masek, J.; Frantik, P.; Fujdiak, R.; Ometov, A.; Hosek, J.; Andreev, S.; Mlynek, P.; Misurec, J. A harmonized perspective on transportation management in smart cities: The novel IoT-driven environment for road traffic modeling. Sensors 2016, 16, 1872. [CrossRef]

104. Zulkifli, C.; Noor, N. Wireless Sensor Network and Internet of Things (IoT) Solution in Agriculture. Pertan. J. Sci. Technol. 2017, 25.

105. Hong, G.-Z.; Hsieh, C.-L. Application of integrated control strategy and bluetooth for irrigating romaine lettuce in greenhouse. IFAC PapersOnLine 2016, 49, 381-386. [CrossRef]

106. Petäjäjärvi, J.; Mikhaylov, K.; Hämäläinen, M.; Iinatti, J. Evaluation of LoRa LPWAN technology for remote health and wellbeing monitoring. In Proceedings of the 2016 10th International Symposium on Medical Information and Communication Technology (ISMICT), Worcester, MA, USA, 20-23 March 2016; pp. 1-5.

107. Jing, L.; Wei, Y. Intelligent Agriculture System Based on LoRa and Qt Technology. In Proceedings of the 2019 Chinese Control And Decision Conference (CCDC), Nanchang, China, 3-5 June 2019; pp. 4755-4760.

108. Borrero, J.D.; Zabalo, A. An autonomous wireless device for real-time monitoring of water needs. Sensors 2020, $20,2078$. [CrossRef]

109. Mark, T.; Griffin, T. Defining the Barriers to Telematics for Precision Agriculture: Connectivity Supply and Demand; Wiley: Hoboken, NJ, USA, 2016. [CrossRef]

110. Mohamed, A. Analysis of Telematics Systems in Agriculture. Master's Thesis, Czech University of Life Sciences Prague, Prague, Czech Republic, 2013.

111. Digital Farming: What Does It Really Mean? And What Is the Vision of Europe's Farm Machinery Industry for Digital Farming? European Agricultural Machinery, CEMA: Bruxelles, Belgium, 2017; p. 9.

112. Jaafar, H.H.; Woertz, E. Agriculture as a funding source of ISIS: A GIS and remote sensing analysis. Food Policy 2016, 64, 14-25. [CrossRef]

113. Yalew, S.G.; van Griensven, A.; Mul, M.L.; Van der Zaag, P. Land suitability analysis for agriculture in the Abbay basin using remote sensing, GIS and AHP techniques. Model. Earth Syst. Environ. 2016, 2, 101. [CrossRef]

114. Hegazy, I.R.; Kaloop, M.R. Monitoring urban growth and land use change detection with GIS and remote sensing techniques in Daqahlia governorate Egypt. Internet J. Sustain. Built Environ. 2015, 4, 117-124. [CrossRef]

115. Rose, I.; Welsh, M. Mapping the urban wireless landscape with Argos. In Proceedings of the 8th ACM Conference on Embedded Networked Sensor Systems, Zürich, Switzerland, 2-5 November 2010; pp. 323-336.

116. Patmasari, R.; Wijayanto, I.; Deanto, R.; Gautama, Y.; Vidyaningtyas, H. Design and realization of automatic packet reporting system (APRS) for sending telemetry data in Nano satellite communication system. J. Meas. Electr. Commun. Syst. 2018, 4, 1-7. [CrossRef]

117. De La Piedra, A.; Braeken, A.; Touhafi, A. Sensor systems based on FPGAs and their applications: A survey. Sensors 2012, 12, 12235-12264. [CrossRef]

118. Murray, S.C. Optical sensors advancing precision in agricultural production. Photon. Spectra 2018, 51, 48. 
119. Novero, A.U.; Pasaporte, M.S.; Aurelio, R.M., Jr.; Madanguit, C.J.G.; Tinoy, M.R.M.; Luayon, M.S.; Nañola, C.L., Jr. The use of light detection and ranging (LiDAR) technology and GIS in the assessment and mapping of bioresources in Davao Region, Mindanao Island, Philippines. Remote Sens. Appl. Soc. Environ. 2019, 13, 1-11. [CrossRef]

120. McRoberts, R.E.; Tomppo, E.O. Remote sensing support for national forest inventories. Remote Sens. Environ. 2007, 110, 412-419. [CrossRef]

121. Weiss, U.; Biber, P. Plant detection and mapping for agricultural robots using a 3D LIDAR sensor. Robot. Auto. Syst. 2011, 59, 265-273. [CrossRef]

122. Biber, P.; Weiss, U.; Dorna, M.; Albert, A. Navigation system of the autonomous agricultural robot Bonirob. In Proceedings of the Workshop on Agricultural Robotics: Enabling Safe, Efficient, and Affordable Robots for Food Production (Collocated with IROS 2012), Vilamoura, Portugal, 11 October 2012.

123. Del-Moral-Martinez, I.; Rosell-Polo, J.R.; Sanz, R.; Masip, J.; Martínez-Casasnovas, J.A.; Arnó, J. Mapping vineyard leaf area using mobile terrestrial laser scanners: Should rows be scanned on-the-go or discontinuously sampled? Sensors 2016, 16, 119. [CrossRef]

124. Montagnoli, A.; Fusco, S.; Terzaghi, M.; Kirschbaum, A.; Pflugmacher, D.; Cohen, W.B.; Scippa, G.S.; Chiatante, D. Estimating forest aboveground biomass by low density lidar data in mixed broad-leaved forests in the Italian Pre-Alps. For. Ecosyst. 2015, 2, 1-9. [CrossRef]

125. Dvorak, J.S.; Stone, M.L.; Self, K.P. Object detection for agricultural and construction environments using an ultrasonic sensor. J. Agric. Saf. Health 2016, 22, 107-119. [PubMed]

126. Gómez Âlvarez-Arenas, T.; Gil-Pelegrin, E.; Ealo Cuello, J.; Fariñas, M.D.; Sancho-Knapik, D.; Collazos Burbano, D.A.; PegueroPina, J.J. Ultrasonic sensing of plant water needs for agriculture. Sensors 2016, 16, 1089. [CrossRef]

127. Andújar, D.; Ribeiro, A.; Fernandez-Quintanilla, C.; Dorado, J. Assessment of a ground-based weed mapping system in maize. Prec. Agric. 2009, 9, 355.

128. García-Ramos, F.J.; Vidal, M.; Boné, A.; Malón, H.; Aguirre, J. Analysis of the air flow generated by an air-assisted sprayer equipped with two axial fans using a 3D sonic anemometer. Sensors 2012, 12, 7598-7613. [CrossRef]

129. Yew, T.K.; Yusoff, Y.; Sieng, L.K.; Lah, H.C.; Majid, H.; Shelida, N. An electrochemical sensor ASIC for agriculture applications. In Proceedings of the 2014 37th International Convention on Information and Communication Technology, Electronics and Microelectronics (MIPRO), Opatija, Croatia, 26-30 May 2014; pp. 85-90.

130. Cocovi-Solberg, D.J.; Rosende, M.; Miró, M. Automatic kinetic bioaccessibility assay of lead in soil environments using flowthrough microdialysis as a front end to electrothermal atomic absorption spectrometry. Environ. Sci. Technol. 2014, 48, 6282-6290. [CrossRef]

131. Shinners, K.J.; Barnett, N.G.; Schlesser, W.M. Yield Monitor for Forage Crops; Wisconsin Alumni Research Foundation: Madison, WI, USA, 2002.

132. Hemmat, A.; Binandeh, A.; Ghaisari, J.; Khorsandi, A. Development and field testing of an integrated sensor for on-the-go measurement of soil mechanical resistance. Sens. Actuators Phys. 2013, 198, 61-68. [CrossRef]

133. Schuster, J.N.; Darr, M.J.; McNaull, R.P. Performance benchmark of yield monitors for mechanical and environmental influences. In Proceedings of the 2017 ASABE Annual International Meeting, Washington, DC, USA, 16-19 July 2017; p. 1.

134. Kumar, A.; Bhatia, A.; Fagodiya, R.; Malyan, S.; Meena, B. Eddy covariance flux tower: A promising technique for greenhouse gases measurement. Adv. Plants Agric. Res. 2017, 7, 337-340.

135. Yunus, M.A.M.; Mukhopadhyay, S.C. Novel planar electromagnetic sensors for detection of nitrates and contamination in natural water sources. IEEE Sens. J. 2010, 11, 1440-1447. [CrossRef]

136. Crabit, A.; Colin, F.; Bailly, J.S.; Ayroles, H.; Garnier, F. Soft water level sensors for characterizing the hydrological behaviour of agricultural catchments. Sensors 2011, 11, 4656-4673. [CrossRef]

137. Howard, B. LIDAR and its use in agriculture; House of Representatives Standing Committee: Canberra, Australian, 2015.

138. Moureaux, C.; Ceschia, E.; Arriga, N.; Béziat, P.; Eugster, W.; Kutsch, W.L.; Pattey, E. Eddy covariance measurements over crops. In Eddy Covariance; Springer: Berlin/Heidelberg, Germany, 2012; pp. 319-331.

139. Kakar, J.A. UAV communications: Spectral requirements, MAV and SUAV channel modeling, OFDM waveform parameters, performance and spectrum management. Master's Thesis, Faculty of the Virginia Polytechnic Institute and State University, Blacksburg, VA, USA, 5 May 2015.

140. Ситдикова, ф.; Тарасова, В.; Сабирова, Р. Computers \& Internet in Daily Use: учебное пособие для студентов факультета BMK. Available online: http:/ / dspace.kpfu.ru/xmlui/handle/net/21267 (accessed on 5 December 2013).

141. Wortmann, F.; Flüchter, K. Internet of things. Bus. Inf. Syst. Eng. 2015, 57, 221-224. [CrossRef]

142. Bronars, S.G. A vanishing Breed: How the Decline in US Farm Laborers Over the Last Decade Has Hurt the US Economy and Slowed Production on American Farms. July 2015. Available online: https://research.newamericaneconomy.org/wp-content/ uploads/2015/08/PNAE_FarmLabor_August-3-3.pdf (accessed on 10 July 2015).

143. Wiggins, M.F. Farm labor and the struggle for justice in the eastern United States. In Latinx Farmworkers in the Eastern United States; Springer: Berlin/Heidelberg, Germany, 2020; pp. 227-251.

144. Defterli, S.G. Review of robotic technology for strawberry production. Appl. Eng. Agric. 2016, 32, 301-318.

145. Bolda, M. Robotic Strawberry Harvester on the Move. Available online: https://ucanr.edu/blogs/blogcore/postdetail.cfm? postnum=8162 (accessed on 17 August 2012).

146. Gorli, R. Future of Smart Farming with Internet of Things. J. Agric. Water Works Eng. 2017, 1, 1-12. 
147. Uddin, M.A.; Mansour, A.; Jeune, D.L.; Ayaz, M.; Aggoune, E.-H.M. UAV-assisted dynamic clustering of wireless sensor networks for crop health monitoring. Sensors 2018, 18, 555. [CrossRef] [PubMed]

148. D'Oleire-Oltmanns, S.; Marzolff, I.; Peter, K.D.; Ries, J.B. Unmanned aerial vehicle (UAV) for monitoring soil erosion in Morocco. Remote Sens. 2012, 4, 3390-3416. [CrossRef]

149. Reinecke, M.; Prinsloo, T. The influence of drone monitoring on crop health and harvest size. In Proceedings of the 2017 1st International Conference on Next Generation Computing Applications (NextComp), Mauritius, Madagascar, 19-21 July 2017; pp. 5-10.

150. Fortes, E.P. Seed plant drone for reforestation. Grad. Rev. 2017, 2, 13-26.

151. Dugdale, S.J.; Malcolm, I.A.; Hannah, D.M. Drone-based Structure-from-Motion provides accurate forest canopy data to assess shading effects in river temperature models. Sci. Total Environ. 2019, 678, 326-340. [CrossRef] [PubMed]

152. Eisenbeiß, H. UAV Photogrammetry; ETH Zurich: Zürich, Switzerland, 2009; p. 236. [CrossRef]

153. Reger, M.; Bauerdick, J.; Bernhardt, H. Drones in Agriculture: Current and future legal status in Germany, the EU, the USA and Japan. Landtechnik 2018, 73, 62-79.

154. Romero-Trigueros, C.; Nortes, P.A.; Alarcón, J.J.; Hunink, J.E.; Parra, M.; Contreras, S.; Droogers, P.; Nicolás, E. Effects of saline reclaimed waters and deficit irrigation on Citrus physiology assessed by UAV remote sensing. Agric. Water Manag. 2017, 183, 60-69. [CrossRef]

155. Hoffmann, H.; Jensen, R.; Thomsen, A.; Nieto, H.; Rasmussen, J.; Friborg, T. Crop water stress maps for an entire growing season from visible and thermal UAV imagery. Biogeosciences 2016, 13, 6545-6563. [CrossRef]

156. Park, S.; Ryu, D.; Fuentes, S.; Chung, H.; Hernández-Montes, E.; O'Connell, M. Adaptive estimation of crop water stress in nectarine and peach orchards using high-resolution imagery from an unmanned aerial vehicle (UAV). Remote Sens. 2017, 9, 828. [CrossRef]

157. Cranston, L.M.; Pembleton, K.G.; Burkitt, L.L.; Curtis, A.; Donaghy, D.J.; Gourley, C.J.; Harrington, K.C.; Hills, J.L.; Pembleton, L.W.; Rawnsley, R.P. The role of forage management in addressing challenges facing Australasian dairy farming. Anim. Prod. Sci. 2020, 60, 26-35. [CrossRef]

158. Spoorthi, S.; Shadaksharappa, B.; Suraj, S.; Manasa, V. Freyr drone: Pesticide/fertilizers spraying drone-an agricultural approach. In Proceedings of the 2017 2nd International Conference on Computing and Communications Technologies (ICCCT), Chennai, India, 23-24 February 2017; pp. 252-255.

159. Superiority, A.; Supremacy, A. Small Unmanned Aerial Systems and Tactical Air Control. Air Space Power J. $2019,33,19$.

160. Faiçal, B.S.; Freitas, H.; Gomes, P.H.; Mano, L.Y.; Pessin, G.; De Carvalho, A.C.; Krishnamachari, B.; Ueyama, J. An adaptive approach for UAV-based pesticide spraying in dynamic environments. Comput. Electr. Agric. 2017, 138, 210-223. [CrossRef]

161. Do, D.; Pham, F.; Raheja, A.; Bhandari, S. Machine learning techniques for the assessment of citrus plant health using UAVbased digital images. In Proceedings of the Autonomous Air and Ground Sensing Systems for Agricultural Optimization and Phenotyping III, Orlando, FL, USA, 16-17 April 2018; International Society for Optics and Photonics: Orlando, FL, USA, 2018; Volume 10664, p. 1066400.

162. Clark, R. Mapping and Estimating Forest Fuel with Radar Remote Sensing; University of Nebraska-Lincoln: Lincoln, NE, USA, 2009.

163. Gnädinger, F.; Schmidhalter, U. Digital counts of maize plants by unmanned aerial vehicles (UAVs). Remote Sens. 2017,9 , 544. [CrossRef]

164. Jin, X.; Liu, S.; Baret, F.; Hemerlé, M.; Comar, A. Estimates of plant density of wheat crops at emergence from very low altitude UAV imagery. Remote Sens. Environ. 2017, 198, 105-114. [CrossRef]

165. Szewczyk, R.; Zieliński, C.; Kaliczyńska, M. Automation 2018: Advances in Automation, Robotics and Measurement Techniques; Springer: Berlin/Heidelberg, Germany, 2018; Volume 743.

166. Torres-Sánchez, J.; Lopez-Granados, F.; Serrano, N.; Arquero, O.; Peña, J.M. High-throughput 3-D monitoring of agricultural-tree plantations with unmanned aerial vehicle (UAV) technology. PLoS ONE 2015, 10, e0130479. [CrossRef] [PubMed]

167. Ranganathan, J.; Waite, R.; Searchinger, T.; Hanson, C. How to Sustainably Feed 10 Billion People by 2050, in 21 Charts. World Res. Inst. 2018, 8, 2019. Available online: https://www.wri.org/blog/2018/12/how-sustainably-feed-10-billion-people-2050-21charts (accessed on 10 April 2020).

168. Otten, J.J.; Diedrich, S.; Getts, K.; Benson, C. Commercial and anti-hunger sector views on local government strategies for helping to manage food waste. J. Agric. Food Syst. Commu. Dev. 2018, 8, 55-72. [CrossRef]

169. Morone, P.; Koutinas, A.; Gathergood, N.; Arshadi, M.; Matharu, A. Food waste: Challenges and opportunities for enhancing the emerging bio-economy. J. Clean. Prod. 2019. [CrossRef]

170. Refed, A. A Roadmap to Reduce US Food Waste by 20 Percent; Rockefeller Foundation: New York, NY, USA, 2016.

171. Kiran, E.U.; Trzcinski, A.P.; Ng, W.J.; Liu, Y. Bioconversion of food waste to energy: A review. Fuel 2014, 134, 389-399. [CrossRef]

172. Jobe, W. A Resource Planning Software for Youth Agripreneurs in Africa. Bachelor's Thesis, Ashesi University, Accra, Ghana, 2019.

173. Footprint, F.F.W.; Change, C. Food Wastage Footprint. Available online: http://www.fao.org/nr/sustainability/food-loss-andwaste (accessed on 22 June 2015).

174. Tubiello, F.N.; Fischer, G. Reducing climate change impacts on agriculture: Global and regional effects of mitigation, 2000-2080. Technol. Forecas. Soc. Chan. 2007, 74, 1030-1056. [CrossRef] 
175. Booth, D. Building capacity: Internet of Things Builds Capacity for Automatic Temperature Logging. J. Environ. Health 2015, 77, 34-37. [PubMed]

176. Jordan, N.; Warner, K.D. Enhancing the multifunctionality of US agriculture. Biol. Sci. 2010, 60, 60-66. [CrossRef]

177. Farooq, M.S.; Riaz, S.; Abid, A.; Umer, T.; Zikria, Y.B. Role of IoT Technology in Agriculture: A Systematic. Electronics $2020,9,319$. [CrossRef]

178. Jasper, C. Take control of your connected devices and manage your M2M worldwide. CIS Syst. 2018, 1-35. Available online: https:/ / www.business.att.com/content/dam/businesscenter/pdf (accessed on 13 December 2018).

179. Kubo, H.; Tanaka, H.; Kakimoto, T. Proposal of five frameworks for constructing keystone strategy. In Proceedings of the 2018 Portland International Conference on Management of Engineering and Technology (PICMET), Honolulu, HI, USA, 19-23 August 2018; pp. 1-11.

180. Williams, S.P. Blockchain: The Next Everything; Scribner: New York, NY, USA, 2019.

181. Smith, A.; Anderson, J. AI, Robotics, and the Future of Jobs. Pew Res. Cen. 2014, 6, 78.

182. York, J. Examining the San Diego Venture Ecosystem. Arch. Bus. Adm. Manag. 2018, 10. [CrossRef]

183. Steinbock, D. Wireless Horizon: Strategy and Competition in the Worldwide Mobile Marketplace; Amacom Books: Seattle, WA, USA, 2003.

184. Turck, M. Growing Pains: The 2018 Internet of Things Landscape. Mattturck. Comput. 2018, 33. Available online: http: / / mattturck.com/iot2018/ (accessed on 9 June 2018).

185. Friedrich, M. Global Hunger on the Rise as Climate Extremes Increase. JAMA 2018, 320, 1969. [CrossRef] [PubMed]

186. Meola, A. Why IoT, Big Data \& Smart Farming Are the Future of Agriculture. Available online: http://www.businessinsider. com/author/andrew-meola (accessed on 24 February 2017).

187. Fiehn, H.B.; Schiebel, L.; Avila, A.F.; Miller, B.; Mickelson, A. Smart agriculture system based on deep learning. In Proceedings of the 2nd International Conference on Smart Digital Environment 2018, Rabat, Morocco, 18-20 October 2018; pp. 158-165.

188. Peters, A. This Strawberry-Picking Robot Gently Picks the Ripest Berries with Its Robo-Hand. Fast Company, 2018. Available online: www.fastcompany.com/40473583/this-strawberry-pickingrobot-gently-picks-the-ripest-berries-with-its-robo-hand (accessed on 2 March 2021).

189. Sylvester, G. E-Agriculture in Action: Drones for Agriculture; Food and Agriculture Organization of the United Nations and International: Rome, Italy, 2018; p. 126. Available online: http://www.fao.org/3/a-i5564e.pdf (accessed on 2 March 2021).

190. Sarbu, I.; Sebarchievici, C. A comprehensive review of thermal energy storage. Sustainability 2018, 10, 191. [CrossRef]

191. Enescu, D.; Chicco, G.; Porumb, R.; Seritan, G. Thermal energy storage for grid applications: Current status and emerging trends. Energies 2020, 13, 340. [CrossRef]

192. Touliatos, D.; Dodd, I.C.; McAinsh, M. Vertical farming increases lettuce yield per unit area compared to conventional horizontal hydroponics. Food Energy Secur. 2016, 5, 184-191. [CrossRef]

193. Khan, N.; Siddiqui, B.N.; Khan, N.; Khan, F.; Ullah, N.; Ihtisham, M.; Muhammad, S. Analyzing mobile phone usage in agricultural modernization and rural development. Int. J. Agric. Ext. 2020, 8, 139-147. [CrossRef]

194. Lyra, D.A.; Ismail, S.; Butt, K.U.R.B.; Brown, J. Evaluating the growth performance of eleven'Salicornia bigelovii'populations under full strength seawater irrigation using multivariate analyses. Aust. J. Crop Sci. 2016, 10, 1429. [CrossRef]

195. Sinn, H.-W. The Green Paradox: A Supply-Side Approach to Global Warming; MIT Press: Massachusetts, UK, 2012.

196. Elsheshtawy, Y. Cities of sand and fog: Abu Dhabi's global ambitions. Evol. Arab City Tradit. Mod. Urban Dev. 2008, 258-304. [CrossRef] 